\title{
Human anisakiasis in Italy: a retrospective epidemiological study over two decades
}

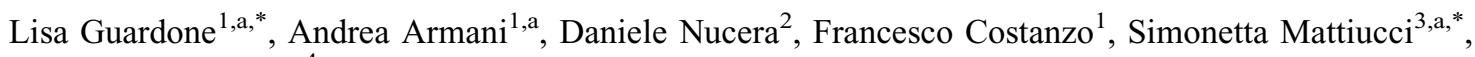 \\ and Fabrizio Bruschi, a \\ ${ }^{1}$ FishLab, Department of Veterinary Sciences, University of Pisa, Via delle Piagge 2, 56124 Pisa, Italy \\ 2 Department of Agriculture, Forestry and Food Science, University of Turin, Largo Braccini 2, 10095 Grugliasco - Torino, Italy \\ 3 Department of Public Health and Infectious Diseases, Section of Parasitology, "Sapienza - University of Rome", Laboratory \\ affiliated to Istituto Pasteur Italia-Fondazione Cenci Bolognetti, P.le Aldo Moro, 5, 00185 Rome, Italy \\ ${ }^{4}$ Department of Translational Research, N.T.M.S., School of Medicine, University of Pisa, via Roma, 55, 56126 Pisa, Italy
}

Received 12 April 2018, Accepted 12 June 2018, Published online 30 July 2018

\begin{abstract}
A retrospective analysis on human anisakiasis in Italy since its first description in 1996 was performed by conducting a literature search. Inclusion criteria based on the presence of a larva and on parasite identification were applied. Epidemiological data and clinical features were analysed. Particular attention was paid to the source of infection. In total, 73 cases were included in the analysis, while 34 were excluded. Cases were reported from eight Italian regions, most frequently Abruzzo, Apulia and Latium. The parasite was detected by endoscopy (51.4\%) or laparotomy (48.6\%). The site of infection was intestinal (42.5\%), gastric (43.8\%), oesophageal (1.4\%) or ectopic (12.3\%). Most of the parasites $(71.0 \%)$ were identified as Anisakis sp. or A. simplex (s.l.). However, when molecular methods were used (21 cases), $A$. pegreffii was always identified. In most of the patients $(65.7 \%)$, the source of infection was raw or undercooked anchovies, followed by "anchovies or sardines" $(15.1 \%)$, generic "raw seafood" (15.1\%), and sardines (1.4\%). In only 2 cases $(2.7 \%)$, the source was not available. This is the first systematic analysis of Italian cases of anisakiasis. The main conclusions derived from the results are: i) attention should be given to the history, in particular when raw marinated anchovies, proven to be the main source of human anisakiasis in Italy, are consumed; ii) in order to assess correct epidemiological data, a confirmed and specific etiological identification should always be sought.
\end{abstract}

Key words: Anisakis sp., Anisakis pegreffi, zoonosis, diagnosis, anchovies, seafood safety.

\begin{abstract}
Résumé - Anisakiase humaine en Italie : une étude épidémiologique rétrospective sur deux décennies. Une analyse rétrospective sur l'anisakiase humaine en Italie depuis sa première description en 1996 a été réalisée en effectuant une recherche bibliographique. Des critères d'inclusion basés sur la présence d'une larve et sur l'identification des parasites ont été appliqués. Les données épidémiologiques et les caractéristiques cliniques ont été analysées. Une attention particulière a été accordée à la source de l'infection. Soixante-treize cas ont été inclus dans l'analyse, tandis que 34 ont été exclus. Les cas ont été signalés dans huit régions italiennes, le plus souvent en Abruzzes, Pouilles et Latium. Le parasite a été détecté par endoscopie (51.4\%) ou laparotomie (48.6 \%). Le site d'infection était intestinal (42.5\%), gastrique (43.8\%), œsophagien (1.4\%) ou ectopique (12.3\%). La plupart des parasites $(71.0 \%)$ ont été identifiés comme Anisakis sp. ou A. simplex (s.l.). Cependant, lorsque des méthodes moléculaires ont été utilisées (21 cas), A. pegreffii a toujours été identifié. Chez la plupart des patients $(65.7 \%)$, la source d'infection était les anchois crus ou insuffisamment cuits, suivis par « anchois ou sardines » $(15.1 \%)$, « fruits de mer crus » $(15.1 \%)$ et sardines $(1.4 \%)$. Dans 2 cas $(2.7 \%)$ la source n'était pas disponible. Cette étude est la première analyse systématique des cas italiens d'anisakiase. Les principales conclusions tirées des résultats sont les suivantes: i) une attention particulière doit être portée à l'anamnèse, surtout lorsque les anchois marinés crus, qui sont la principale source d'anisakiase humaine en Italie, sont consommés; ii) une identification parasitologique doit toujours être effectuée pour valider les données épidémiologiques.
\end{abstract}

\section{Introduction}

*Corresponding author: lisa.guardone@for.unipi.it; simonetta.mattiucci@uniroma1.it

${ }^{\mathrm{a}}$ These authors contributed equally to the study.
Parasitic zoonoses of food safety concern are generally underestimated but are increasing dramatically [20]. Since notification to public health authorities is not mandatory for most parasitic diseases, official reports do not reflect the true 
prevalence or incidence of these diseases [44]. In addition, while the importance of meat-borne parasitic zoonoses such as trichinellosis and cysticercosis has long been recognised, fish-borne parasitic diseases like opisthorchiasis, clonorchiasis, intestinal trematodiasis, diphyllobothriasis or anisakidosis have received, until two decades ago, less attention, despite the large numbers of human infections [30, 46, 85]. This is probably due to the fact that in the past, the risk of human infection with such parasites was considered to be limited to populations living in low- and middle-income countries in distinct geographic regions. However, the geographical limits and populations at risk have expanded because of growing international markets, improved transportation systems, demographic changes, an increasing population of susceptible persons, and changing culinary habits, leading to a renewed interest in these parasitic infections [41, 85].

"Anisakidosis" is the zoonotic disease caused by the third larval stage of anisakid nematodes, most frequently belonging to the Anisakis and Pseudoterranova genera, or, very rarely, to species of the genus Contracaecum [57]. Infection due to larvae of the genus Anisakis may be indicated as "anisakiosis" [57], even though the term "anisakiasis" is more frequently used [71, 110, 114]. Adult worms are found in the stomach of marine mammals (cetaceans); eggs are passed in their faeces and become embryonated in sea water. Crustaceans (krill) become infected with larval stages. When crustaceans are preyed on by fish or squid, the third stage larvae infect their viscera encysting on organ surfaces and, eventually, in the musculature $[60,76]$. Humans represent an accidental host of these parasites; the zoonotic infection is acquired through the consumption of raw or undercooked infected marine fish or squids $[68,73]$. The larvae do not develop further in humans; however, they can penetrate the gastrointestinal mucosa or, more rarely, other organs, often with clinical consequences. In addition, these parasites may generate potentially allergic reactions, characterised by urticaria or angio-oedema [11, 37, 75].

The first zoonotic case attributed to Anisakis species was described in the Netherlands around 1960, and correlated to the consumption of raw herrings [118]. Recent data stem from a systematic review of the literature by Orphanet, with an estimated worldwide incidence of 0.32/100,000) [88]. Japan and other Far-Eastern countries account for the vast majority of cases, reflecting the traditional frequent consumption of raw fish in these regions, where anisakiasis is considered a relatively common public health issue $[11,76,90]$. It is estimated that more than 2500 cases occur annually in Japan. In Europe, the exact incidence is difficult to establish, but it seems to be lower than 20 cases per country per year [2]. No data on human cases of anisakidosis are reported in the most recent European Union summary report on trends and sources of zoonoses, zoonotic agents and food-borne outbreaks [42]. The lack of data on certain parasitic zoonoses which are known to occur in the European Union in the EFSA reports has already been pointed out by other authors, who highlighted that few parasitic infections are considered [41]. In fact, the only parasitic zoonoses currently included are trichinellosis, echinococcosis and toxoplasmosis [42]. A very recent study estimated the incidence of anisakidosis in France by analysing data from the parasitology laboratories of university hospitals. A total of 37 cases in the years 2010-2014 were found [119], showing a decrease in comparison with a similar study conducted between 1985 and 1987 [54]. As regards the United States of America, an incidence of 10 cases per year was reported [2]; however, the exact frequency of anisakidosis is unknown [17].

In Italy, the first confirmed human case was described in 1996 [113]. Following this first description, the number of reported human cases in Italy has steadily increased. However, the real occurrence of anisakiasis in the Italian population could be underestimated, since scientific data are scattered and hospital reports are generally not published. As a consequence, contrasting estimates of the number of cases can be found [34, 38, 51, 76].

The aim of the present study was to conduct a retrospective analysis on the human cases of anisakiasis described in Italy since 1996. The epidemiological data and clinical features of the reported cases were analysed. Particular attention was paid to the main sources of infection of humans by Anisakis spp., whenever known.

\section{Materials and methods \\ Literature search and selection of cases}

To review cases of Anisakis spp. infections in humans in Italy, literature data were identified on the PubMed and Google Scholar databases using the following keywords: (Anisakidae OR Anisakis) AND (human OR human cases) OR (anisakidosis OR anisakiasis) AND Italy. The search was conducted using the terms together or combined differently in order to retrieve the maximum number of records (Appendix A). Then, the reference list of the screened articles was also checked for eligible new records. Only papers published in English, French, Italian and Spanish were included. The search was concluded in January 2018. In addition, 15 cases, reported in a thesis [40] and confirmed by the supervisor Dr. Paolo Fazii, Santo Spirito Hospital, Pescara (personal communication) were included.

After deduplication (conducted by comparing the sex, age, geographical location, clinical and parasitological features of the different patients and excluding overlapping cases), cases were considered eligible (confirmed cases) and included in the study when the following conditions were met: i) an Anisakis spp. larva was detected in the patient (by endoscopic removal or on histological examination following surgical removal of biopsy tissue), ii) identification of the parasite was performed, at least to genus level, by microscope observation of morphological characters referring to an Anisakis spp. larva, or to species level by the use of different molecular tools. The excluded cases were considered as "suspected".

\section{Data Extraction}

For each study, the following data were extracted using predefined data fields in an Excel file: number of patients involved, age, sex, geographical origin, source of infection, parasite detection and identification method, site of infection and number of larvae found, symptoms, time between the ingestion of infected 
food and the onset of symptoms, treatment, outcome, occurrence of allergic reactions, and seropositivity.

\section{Statistical analysis}

Associations among variables were investigated using the chi-square test. Results were considered significant when $p<0.05$ and highly significant when $p<0.001$. Investigated couples of associated variables were: i) site of infection of the larva and time of symptom onset; ii) site of infection of the larva and treatment; iii) symptoms and time of onset; iv) symptoms and treatment. All the variable categories were mutually exclusive and each case was unambiguously classified. A multivariate analysis was conducted assuming as dependent variable the method used for larval detection (endoscopy/laparotomy), and the site of infection of the larva and the time of symptom onset as independent variables.

\section{Results}

\section{Literature search and selection of cases}

A total of 47 literature records were selected and further screened. Out of these 47 records, 28 reported cases that matched the inclusion criteria (presence of a larva and identification to genus or species level) were included in the study, while a further 19 were excluded (Table 1). The 28 publications included in the study described 65 putative cases. However, only 58 of them met the criteria and were further selected for the analysis. With the addition of the 15 cases reported in [40] and confirmed by P. Fazii, a total of 73 cases were included in the analysis. Likewise, 34 "suspected" cases ( 27 from the 19 excluded records and 7 from the 28 included records) were excluded.

\section{Age distribution and sex ratio}

Age was available for 58 patients: the mean age was 44.4 $(S D=12.9)$ and the age range 19-86. The disease showed the highest frequency in the thirties age group (29.3\%), followed by forties $(25.9 \%)$, fifties $(25.9 \%)$, over sixties $(10.3 \%)$ and twenties (6.9\%). Similarly, also in the study of Sohn et al. [110], the highest relative frequency of occurrence was found in the thirties and forties age groups and the lowest in teens. A higher frequency in adults than in children was also observed by Pampiglione et al. [90].

As regards the sex ratio, gender was available for 60 patients: a slight difference, although not significant, was observed as 25 were men and 35 were women. A significant predominance of women was found in France [119].

\section{Geographical distribution}

The cases for which a geographical origin was available $(N=67,91.8 \%)$ were distributed in eight Italian regions. In 13 of these cases, the geographical origin was attributed on the basis of the hospital where the patient was admitted, since no explicit information was given in the text. Three Italian regions recorded a high frequency level: Abruzzo $(N=24$, $35.8 \%)$, Apulia $(N=20,29.8 \%)$, and Latium $(N=10$,
$14.9 \%)$. The remaining cases occurred in: Tuscany $(N=5$, $7.5 \%)$, Campania $(N=3,4.5 \%)$, Molise $(N=2,3.0 \%)$, Sicily $(N=2,3.0 \%)$ and Liguria $(N=1,1.5 \%)$. Results are shown in Fig. 1.

\section{Source of infection}

The source of infection was reported in 71 cases $(97.2 \%)$. In most of the patients $(N=48,65.7 \%)$, the infection was related to the consumption of raw or undercooked anchovies. In 11 other cases $(15.1 \%)$, it was related to the consumption of generically defined "anchovies or sardines" and in one case $(1.4 \%)$ to sardines (Appendix B). In the remaining 11 cases $(15.1 \%)$, the source of infection was only mentioned as raw fish or seafood.

\section{Parasite detection and identification method}

The parasite was detected by endoscopy $(N=37,51.4 \%)$ or by laparotomy $(N=35,48.6 \%)$. Results of the multiple logistic regression showed that only the location (gastric) was significantly associated with the detection method (endoscopy) $(\mathrm{OR}=35.70 ; 95 \%$ confidence interval 5.3-293.3), whereas the time of symptom onset was not statistically associated, probably due to the small sample size in each category of this covariate.

In most of the cases, the parasite was generically identified as Anisakis spp. $(N=42,57.5 \%)$, histologically or by microscopy. In 12 cases (16.4\%), the identification achieved by histology or light and scanning microscopy was A. simplex (sensu latu). In all the 21 cases in which specific molecular methods were used, the identified parasite was $A$. pegreffii. Details are reported in Appendix B.

\section{Site of infection and number of larvae}

The site of infection was classified on the basis of the parasite localisation: gastric (including the oesophagus), or intestinal tract, and ectopic. As regards the gastric localisation, in 32 of the patients the larva was found in the stomach (43.8\%) and in 1 in the oesophagus (1.4\%), while it was located in the intestine in 31 patients $(42.5 \%)$. The intestinal location affected the ileum $(N=14)$, the colon $(N=11)$, the caecum $(N=4)$ and the jejunum $(N=2)$. Ectopic locations were found in 9 patients $(12.3 \%)$, more precisely the peritoneum $(N=8)$ and the spleen $(N=1)$ (Appendix B).

With the exception of two cases (described in [75] and [40]) in which 2 and 3 larvae were endoscopically removed, a single larva was always found.

\section{Symptoms and time between the ingestion of infected food and the onset of symptoms}

In the large majority of the cases, the patients presented with acute or chronic abdominal pain of variable intensity $(N=68: 93.1 \%)$. Abdominal pain was frequently associated with nausea (16 cases), less frequently with diarrhoea $(N=2)$, fever $(N=1)$ or constipation $(N=1)$. In 10 cases, it was accompanied by an allergic reaction (3 cases reported in 
Table 1. List of included and excluded cases reported in scientific articles, with some of the most relevant data.

\begin{tabular}{|c|c|c|c|c|}
\hline Reference & Number of patients & Site of infection & Method used for larval detection & Etiological agent \\
\hline \multicolumn{5}{|l|}{ Included records } \\
\hline Stallone et al. [113] & 1 & Gastric & - & Anisakis sp. \\
\hline Cancrini et al. [24] & 1 & Extra-gastrointestinal & Laparotomy & Anisakis sp. \\
\hline Cancrini et al. [23] & 1 & Gastric & Endoscopy & Anisakis sp. \\
\hline D'Amelio et al. [35] & 1 & Gastric & Endoscopy & A. pegreffii* \\
\hline Maggi et al. [64] & $3(4)^{\mathrm{a}}$ & $\begin{array}{l}\text { Gastric (1), intestinal (1), } \\
\text { extra-gastrointestinal (1) }\end{array}$ & Laparotomy & A. simplex (s.l.) \\
\hline Pampiglione et al. [90] & 11 & $\begin{array}{l}\text { Gastric (2), intestinal (3), } \\
\text { extra-gastrointestinal (5), } \\
\text { spleen (1) }\end{array}$ & Endoscopy, laparotomy & Anisakis sp. \\
\hline Caramello et al. [25] & 1 & Intestinal & Laparotomy & Anisakis sp. \\
\hline Moschella et al. [83] & 1 & Intestinal & Laparotomy & Anisakis sp. \\
\hline De Nicola et. al. [39] & 1 & Intestinal & Laparotomy & A. simplex \\
\hline Montalto et al. [82] & 1 & Intestinal & Laparotomy & A. simplex (s.l.) \\
\hline Pellegrini et al. [91] & 1 & Intestinal & Laparotomy & A. simplex (s.l.) \\
\hline Fazii et al. [47] & 3 & Gastric (2), intestinal (1) & Endoscopy & Anisakis sp. \\
\hline Avellino et al. [12] & 1 & Esophagus & Endoscopy & A. pegreffii* \\
\hline Ugenti et al. [117] & 3 & Gastric & Endoscopy & A. simplex (s.l.) \\
\hline Fumarola et al. [49] & 2 & Gastric & Endoscopy & A. pegreffi* ${ }^{*}$ \\
\hline Marzocca et al. [67] & 1 & Intestinal & Laparotomy & A. simplex (s.l.) \\
\hline Aloia et al. [3] & 1 & Intestinal & Endoscopy & A. simplex (s.l.) \\
\hline Mattiucci et al. [74] & 1 & Intestinal & Laparotomy & A. pegreffi $i^{*}$ \\
\hline Pontone et al. [96] & $1(2)^{b}$ & Gastric & Endoscopy & Anisakis sp. \\
\hline Mattiucci et al. [71] & 8 & Gastric (6), (GAA) (2) & Endoscopy & A. pegreffii* \\
\hline Mumoli and Merlo [84] & 1 & Intestinal & Endoscopy & A. simplex (s.l.) \\
\hline Andrisani et al. [5] & 1 & Intestinal & Endoscopy & Anisakis sp. \\
\hline Baron et al. [15] & $1(6)^{\mathrm{c}}$ & Intestinal & Laparotomy & Anisakis sp. \\
\hline Mariano et al. [65] & 1 & Gastric & Endoscopy & Anisakis sp. \\
\hline Carbotta et al. [26] & 1 & Intestinal & Laparotomy & Anisakis sp. \\
\hline Mattiucci et al. [70] & 5 & Gastric (GAA) & Endoscopy & A. pegreffii* \\
\hline Mattiucci et al. [75] & 3 & Gastric (1), intestinal (2) & Endoscopy, laparotomy & A. pegreffi $i^{*}$ \\
\hline Palma et al. [89] & 1 & Gastric & Endoscopy & Anisakis sp. \\
\hline Total $(28 \text { records })^{\mathrm{e}}$ & $58(65)^{\mathrm{d}}$ & & & \\
\hline \multicolumn{5}{|l|}{ Excluded records } \\
\hline Ioli et al. [55] & 1 & - & - & - \\
\hline Riva et al. [101] & 4 & - & - & - \\
\hline Bavastrelli et al. [16] & 1 & - & - & - \\
\hline Testini et al. [116] & 1 & - & - & - \\
\hline Piscaglia et al. [95] & 1 & - & - & - \\
\hline Pezzilli et al. [93] & 1 & - & - & - \\
\hline Biondi et al. [18] & 1 & - & - & - \\
\hline Rea et al. [99] & 1 & - & - & - \\
\hline Zullo et al. [122] & 1 & - & - & - \\
\hline Filauro et al. [48] & 1 & - & - & - \\
\hline Sola et al. [111] & 1 & - & - & - \\
\hline Taranto et al. [115] & 6 & - & - & - \\
\hline Fava et al. [45] & 1 & - & - & - \\
\hline Griglio et al. [51] & 1 & - & - & - \\
\hline Bucci et al. [21] & 1 & - & - & - \\
\hline Cesaro et al. [29] & 1 & - & - & - \\
\hline Marra et al. [66] & 1 & - & - & - \\
\hline Zippi et al. [121] & 1 & - & - & - \\
\hline Zanelli et al. [120] & 1 & - & - & - \\
\hline Total (19 records) & 27 & - & - & - \\
\hline
\end{tabular}

${ }^{\text {a }}$ Four reported cases but only 3 confirmed by histology;

${ }^{\mathrm{b}}$ In the second case no larva was found;

${ }^{c}$ Six cases are reported but only one shows photos and description of the histological section;

d Total number of cases reported in the 27 articles;

${ }^{\mathrm{e}}$ In addition, 15 cases reported in a thesis (De Rosa [40]) and confirmed by Dr. Fazii, not shown in the table, were included in the analysis.

* Molecular identification. 


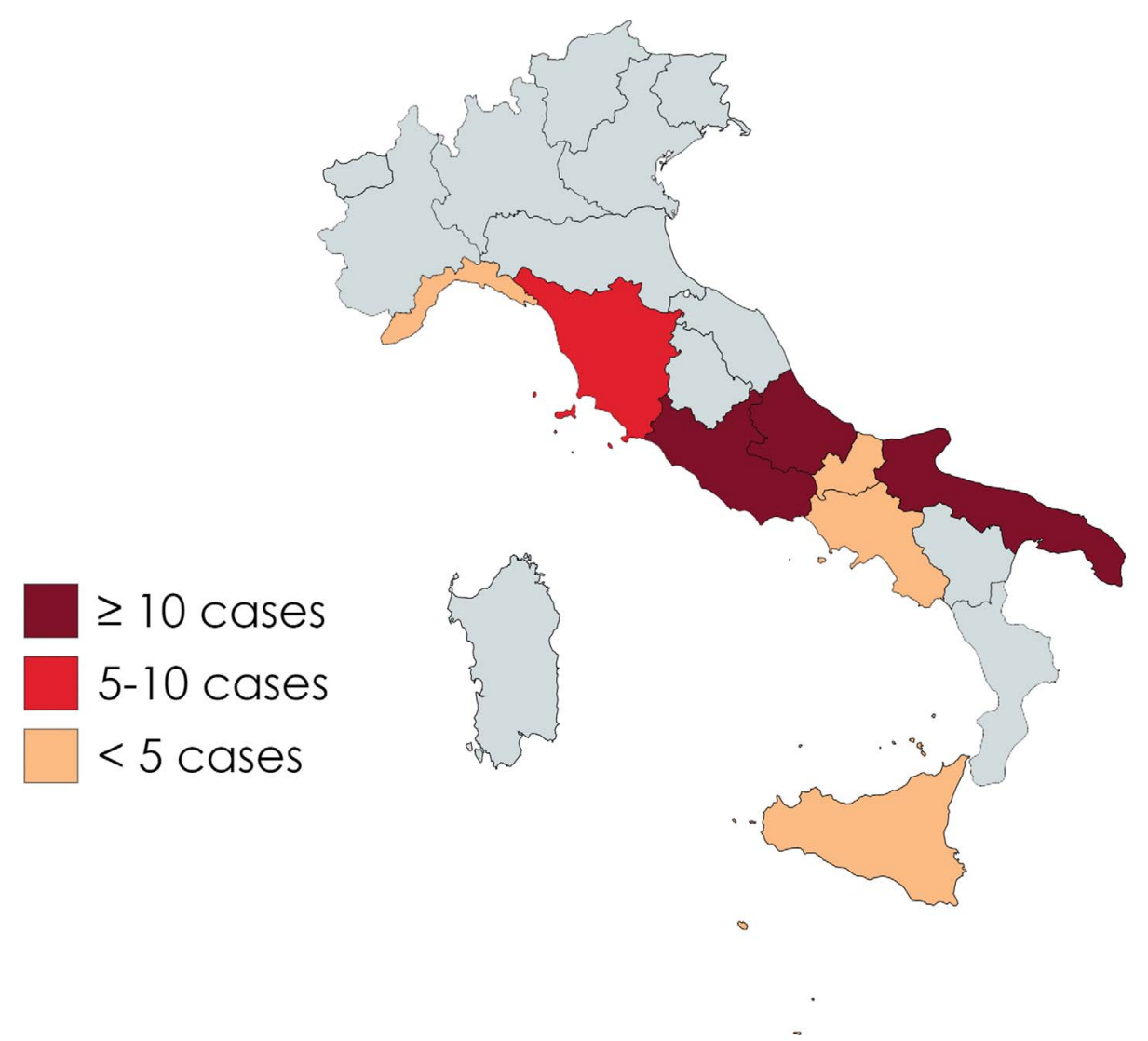

Figure 1. Map of the distribution of the Italian cases of anisakiasis included in the present study, divided per region. Created with Mapchart.net.

[71] and 5 in [70]; 1 case described by Fazii et al. [47] and 1 case described by D'Amelio et al. [35]; see also Serodiagnosis in the analysed cases section). In one case, chest discomfort was the only symptom [96], and in two cases, no symptoms were present [47]. In another case, the patient showed only rectal bleeding, which was first attributed to a possible haemorrhoidal problem, but a larva was found on the colon mucosal surface after colonoscopy [3] (Appendix B).

As regards symptom onset, in most of the cases $(69.9 \%)$ symptoms were acute (occurring within $24 \mathrm{~h}, N=28$ ) or sub-acute (occurring within one week, $N=23$ ). A highly significant statistical association $(p<0.001)$ was observed between the larval localisation and the time of symptom onset: gastric cases presented symptoms within $24 \mathrm{~h}$ of the ingestion of a food at risk, while onset was subacute or chronic in extragastric locations. In 14 other cases, the precise timing of consumption of food at risk was unknown, but the patients were habitual consumers of raw or undercooked fish. Most of these cases were extra-gastric ( 4 omentum, 3 ileum, 2 colon, 1 caecum, 1 spleen), while 3 were gastric. In only one case, the consumption occurred a few months before, and in two cases the time was not known or specified (Appendix B).

\section{Treatment and outcome}

In 36 cases $(49.3 \%)$, the treatment was the removal of the larva or of the lesion with the larva by biopsy forceps during endoscopy. Overall, 29 of these cases were gastric and a highly significant statistical association $(p<0.001)$ was found between endoscopic removal of the larva and gastric localisation. In all cases, this was the only treatment performed. In the 7 remaining cases treated by endoscopy, the site of infection was the colon (6) or the oesophagus (1).

In 36 cases (49.3\%), the patients underwent surgery for the removal of the lesion, generally a mass or an ulcer. In one case, the treatment was not available. In 34 of the cases treated with surgery (94.4\%), the localisation of the larva was extra-gastric (25 intestinal localisations, 8 mesentery/omentum, 1 spleen), while only 2 patients who underwent surgical treatment had gastric anisakiasis. The statistical analysis showed a highly significant association $(p<0.001)$ between the surgical treatment and an extra-gastric site of infection of the larva. On the contrary, due to the non-specificity of symptoms, no significant association was observed between symptoms and time of onset nor with symptoms and treatment. In all the cases, the detection method (endoscopy/laparotomy) corresponded to the treatment (endoscopic removal/surgical treatment).

In most of the analysed cases $(N=47,64.4 \%)$, no data on the outcome were reported and in one case, follow-up was in progress. When the post-treatment course was described, it was always regular and uneventful. In particular, a regular post-operative course was described for 10 of the patients who underwent surgery, and for 10 patients who were treated by endoscopy. 
Table 2. Available data on the serodiagnosis from the included cases.

\begin{tabular}{|c|c|}
\hline Reference & eropositivity and detection method \\
\hline Fazii et al. [47] & $\begin{array}{l}\text { High titre of anti-Anisakis antibodies (IgE } 13.80 \mathrm{U} \text { RAST - Class 4/IgG: } 6.3 \mathrm{E} \text { ) } \\
\text { High titre of anti-Anisakis antibodies } \\
\text { High titre of anti-Anisakis antibodies }\end{array}$ \\
\hline Aloia et al. [3] & $\begin{array}{l}\text { Serum immunoglobulin (IgM, IgA, IgG and total IgE) levels were within the normal range. Specific IgE to } A \text {. simplex, } \\
\text { using an ImmunoCAP System (Phadia), was negative }(<0.35 \mathrm{kU} / \mathrm{L})\end{array}$ \\
\hline onto & Positive anti-Anisakis larvae immunoglobulin G antibody \\
\hline Matti & $\begin{array}{l}\text { Total IgE: 1,479; IgE-As (ImmunoCAP ISAC diagnostic test, Phadia, Uppsala, Sweden): }>100 \text {; WB positive for } A n i \\
\text { sl (24 kDa) } \\
\text { Total IgE: } 2,180 \text {; IgE-As (ImmunoCAP ISAC diagnostic test, Phadia, Uppsala, Sweden): }>100 \text {; WB positive for Ani } \\
\text { s1 (24 kDa) } \\
\text { Total IgE: } 4727 \text {; IgE-As (ImmunoCAP ISAC diagnostic test, Phadia, Uppsala, Sweden): }>100 \\
\text { Total IgE: 511; IgE-As (ImmunoCAP ISAC diagnostic test, Phadia, Uppsala, Sweden): } 21.2 \\
\text { Total IgE: } 2,062 \text {; IgE-As (ImmunoCAP ISAC diagnostic test, Phadia, Uppsala, Sweden): } 89.3\end{array}$ \\
\hline Mattiucci et al. [70] & 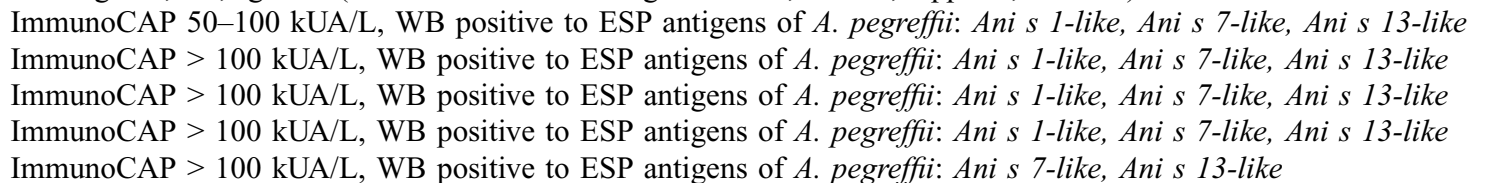 \\
\hline Mattiucci et al. [75] & $\begin{array}{l}\text { WB assay IgE, IgG4 reactivity versus Ani s 13-like and Ani s 7-like } \\
\text { WB assay only IgG reactivity versus Ani s 13-like and Ani s 7-like } \\
\text { WB assay, IgE and IgG reactivity versus Ani s 13-like, Ani s 7-like and Ani s 1-like }\end{array}$ \\
\hline
\end{tabular}

\section{Occurrence of allergic reactions}

An allergic reaction was described in 10 cases (13.7\%): 1 reported in D'Amelio et al. [35], 1 in Fazii et al. [47], 3 in Mattiucci et al. [71] and 5 in Mattiucci et al. [70]. In all cases, the symptoms were strictly associated with the ingestion of contaminated fish (confirmed by the subsequent retrieval of a larva). In 8 cases, high titres of IgE were found. In 5 cases, in particular (Mattiucci et al. [70]) iCAP was $>100 \mathrm{kUA} / \mathrm{L}$ and IgE-WB positive to excretory/secretory (ES) antigens of A. pegreffii (Ani s 1-like, Ani s 7-like, Ani s 13-like). The symptoms varied from localised or generalised oedema to urticaria, and were generally associated with abdominal pain. In addition, in one article reporting 11 cases [86], it was mentioned that recurrent oedema in the form of transient swelling, erythema, rashes or widespread itching occurring before or during the development of the infection were rarely observed, again associated with epigastric pain.

\section{Serodiagnosis in the analysed cases}

The serodiagnosis was performed in 26 cases $(35.6 \%)$, using the UniCAP or ImmunoCAP (Phadia) methods $(N=16)$, the Lopharma method $(N=3)$ and/or immunoblotting $(N=13)$. In 4 cases, the diagnostic method was not mentioned. Only one article reported seronegativity (using an ImmunoCAP System, [3]), while for the remaining cases serological tests were not mentioned. Details on data for the serodiagnosis are reported in Table 2. As regards the interpretation of the results obtained with different methods, in a recent study, IgE response was analysed by an immunoblotting (WB) assay, using both ES antigens and crude extract (CE) of $A$. pegreffii larvae, and the results were compared with those achieved by the conventional immunological method for Anisakis allergy (i.e. immunoCAP). Although WB appeared to be more specific, iCAP and WB exhibited a high concordance value $(\kappa=1.00)$ when the iCAP value was $<0.35$ (negative result) and $>50.0$ (positive result) [70].

\section{Discussion}

\section{Literature search and selection of cases}

Despite the strict selection applied, the number of cases detected is higher than the number indicated in other recent Italian studies [34, 38]. In addition, although great efforts were made during the bibliographic investigation, it is known that other cases (not described in the literature) are also reported annually by the health authorities, mainly in regions of Central and Southern Italy [38]. However, access to these data is generally not public and a database at the national level is lacking.

The low number of documented cases is in contrast with the frequent occurrence of these parasites in a wide number of Mediterranean fish species [60,68], including those consumed raw or marinated, suggesting that human infections with Anisakis spp. in Italy might still be significantly underestimated $[68,76]$, due to the high frequency of self-limiting infections [38], to underreporting, and to missed or incomplete diagnosis. In this regard, it should also be stressed that the selection applied in this study led to the exclusion of 34 "suspected" cases ( 27 from the excluded cases and 7 from the included cases). Other authors already pointed out that many more cases may be suspected if serologically positive subjects, but without detection of parasites, are considered [90]. However, in order to estimate correct epidemiological data, a precise etiological identification should always be sought (see Parasite detection and identification method section). An additional factor that can contribute to the underestimation of cases due to missed or incomplete diagnosis is the general low level of knowledge of seafood parasitology among Italian medical 
doctors. In fact, in Italy as in other European countries, teaching parasitology to medical students is met with a decreasing level of interest [19]. The same factors causing underestimation of Anisakis spp. are likely to also influence underestimation of imported infections by Pseudoterranova spp. in Italy.

\section{Geographical distribution}

The infection appears to be more frequent in coastal areas, where there is a higher tendency to consume seafood. The results of the present retrospective study are in agreement with other studies claiming that the disease is more widespread in the regions of Southern and Central Italy (Abruzzo, Molise, Campania, Puglia, and Sicily) [34]. On the contrary, no marked geographical differences were found in the recent study conducted in France [119]. However, the presence of specialised researchers or centres in specific regions may represent a bias in the geographical distribution of cases, influencing the attention to specific diseases which may be more frequently described in such areas. This phenomenon has already been observed by other authors [110] and it had already been hypothesized for the Abruzzo region, where the existence of a specialised group of experts likely favoured the diagnosis of a higher number of cases [40]. In this respect, the continuous education of physicians and the creation of dedicated centres distributed throughout the country appears important for correct diagnosis and for the acquisition of up-to-date epidemiological data. An example is the Apulia region where, given the high frequency of the disease, also confirmed by the results of the present study, a Technical Working Group for the "prevention of Anisakis spp. in fishery products" was created in 2011, with the aim of implementing a system of surveillance in coordination with the Regional Epidemiological Observatory (https://www.sanita.puglia.it/archivio-news_det/-/journal_content/56/20182/prevenzione-dell-anisakiasi-da-consumo-diprodotti-della-pesca).

\section{Source of infection}

It is widely recognised that the source of human anisakiasis relates to the geographical areas and to different eating habits [110]. Several commercial fish species distributed in European markets are at risk of carrying zoonotic anisakid nematodes $[43,68]$. Raw or pickled herring, hake, mackerel, anchovy and cod are known to be important infection sources in other European countries, such as the Netherlands and Spain [10, $102,118]$. Spain, in particular, is considered to have the highest incidence of anisakiasis in Europe, predominantly through consumption of the traditional marinated dish "anchovies in vinegar". However, the actual human anisakiasis burden is unknown due to the scarcity of epidemiological data [13, 43]. Anchovies (Engraulis encrasicolus) are traditionally consumed raw following simple home-made preparations (in lemon or vinegar, according to the regional/local traditional recipes, i.e., "marinated anchovies") also in Italy and in Croatia $[33,79]$. Salmon was shown to be the food source most frequently involved in human cases in France, followed by anchovies [119].
On the basis of the data analysis, anchovies are confirmed as the main species at risk in Italy, in agreement with [71, 7476]. In Italy, E. encrasicolus is the main fished species by weight, corresponding to $25-35 \%$ of the total catches of marine fishes between 2010 and 2014 (http://www.fao.org/fishery/topic/16140/en). As mentioned, this fish species is frequently consumed in recipes traditionally prepared without thermal processing, such as marinated anchovies. Accordingly, in the vast majority of the cases analysed here, it was reported that the fish had been consumed as marinated or pickled $(N=53,72.6 \%)$.

Besides anchovies, pilchards (or sardines) were also indicated as a possible source of infection in the literature analysed. In 11 cases, in fact, the infection was related to the consumption of generically indicated "anchovies or sardines", and in one case to sardines. Epidemiological data regarding the two fish species are available in the literature. The occurrence of Anisakis spp. in anchovies from the Mediterranean Sea has been reported in a number of studies $[6,27,31,32,38,53,78$, $80,94,100,106]$ with variable infection levels. A summary of most of the data deriving from these surveys is reported in Cipriani et al. [33]. This latter study conducted an extensive survey on anchovies in different Mediterranean fishing grounds, showing that levels of infection with $A$. pegreffii significantly varied in relation to areas and, to a lesser extent, fish size. In particular, the highest levels of infection were found in the Central (70.8\%) and South Adriatic Sea (55.8\%), while anchovies from Southern Sicily, the Ionian and Alboran Seas were uninfected [33]. High Anisakis spp. prevalence values (reaching in some batches $83 \%$ and $29 \%$ in the viscera and flesh, respectively) were also found in the north-east Atlantic [102]. Similarly, differences in the infection level of Anisakis spp. in European pilchards (sardines) from the Mediterranean Sea have been reported [27, 78, 81, 94, 106], ranging from $0 \%$ in the Ligurian Sea [106], to $28.3 \%$ along the Atlantic Spanish coast [81]. In a recent study, the prevalence (varying from 0 to $44.9 \%$, average $12.2 \%$ ) was confirmed to be highly influenced by both geographic location and host size. In this case, the highest prevalence $(44.9 \%)$ was recorded in western parts of the Mediterranean, in particular off west Sardinia [22]. Sardines from the Atlantic showed comparatively high Anisakis spp. prevalence in both viscera (approximately $62 \%$ ) and flesh (17\%) in another recent survey [60].

Importantly, in both anchovies and sardines, Anisakis spp. larvae were also found in the muscle, although with lower prevalence values compared to viscera $[22,33,60]$.

Thus, given the variable prevalence values found in anchovies and in sardines, it is difficult to hypothesize how many ambiguous cases could be attributed to one species rather than to the other. In relation to this, we should also note that many consumers are not able to clearly distinguish anchovies and sardines, leading to a certain degree of confusion between the two species, especially if marinated.

As regards dish preparation, few details were given and only the studies of Fumarola et al. [49] and Mattiucci et al. [70] specified that marinated/pickled anchovies had been domestically prepared, while in another study it was specified that the dish had been prepared from raw fresh anchovies [71]. Nematodes are highly resistant to traditional marinating 
methods, surviving for periods of a few days up to several weeks, depending on the concentration of salt, acetic acid, and marinating times $[1,4,56]$. In the traditional marinating process, the fish is left in a solution of vinegar and salt for$<24$ h. However, Sánchez-Monsalvez et al. [105] reported that the death of all larvae in fillets exposed to vinegar did not occur until day 13. Therefore, preventive freezing of such products is compulsory by law in order to reduce the parasite hazard [36]. The industrial production of salted or marinated anchovies generally assures devitalisation of the larvae [4, 97], and only dead larvae were found in two recent studies on industrially [52] or professionally [112] marinated anchovies.

Although Italian legislation directed at domestic preparation states that:

In case of consumption as raw, marinated or not fully cooked fish, the product must first be frozen for at least 96 hours at $-18{ }^{\circ} \mathrm{C}$ in a domestic freezer marked with three or more stars [59]

fish prepared at home still represents a particular challenge for risk prevention, as also observed by other authors [60]. In fact, domestic preparation is often conducted without such previous freezing [60], since it can affect the taste characteristics of the products [4], or by freezing for an inadequate period of time [90], allowing survival of the larvae and involving a transmission risk. Interestingly, a significantly positive correlation between the post-mortem migration of $A$. pegreffii in anchovy and incorrect storage temperature and time was demonstrated. In particular, the increase of infection values with $A$. pegreffi in anchovy fillets was statistically positively related to the increase of the temperature and time of storage [32]. Larval migration during storage at $4{ }^{\circ} \mathrm{C}$ was also observed by Šimat et al. [109], as well as an influence of biogenic amines and pH. Moreover, it was recently shown that Anisakis spp. may present some freezing tolerance, allowing partial survival when submitted to domestic freezing, owing to insufficiently low temperatures, temperature inhomogeneity, and different freezing rates [104].

Among the 11 cases for which no reference to a fish species was made, 2 of them specified that the source food was sushi $[40,84]$. Although sushi and sashimi are a food at risk for transmitting anisakidosis, various marine fish species that are preferentially served in Japanese restaurants and sushi bars in Japan such as tuna, yellow tail, red snapper, salmon, and flatfish/flounder are less contaminated or even free of Anisakis larvae. In contrast, other popular and cheaper marine fish, such as cod, herring, mackerel, and squid that are mainly consumed at home or at local restaurants in Japan, tend to be heavily infected with Anisakis spp. larvae [86].

Similarly, the species most frequently used in sushi preparation in Italy like salmon, gilt-head seabream, sea bass and tuna $[8,9]$, are rarely infected by anisakids. In fact, with the exception of tuna, they are farmed species for which the parasitological risk is usually lower [7, 43, 68, 92]. This might explain why, despite the fact that culinary habits have changed in Italy and that, similarly to other European countries, there has been a strong increase in sushi/sashimi consumption, no increase of published cases during the studied period was observed. Despite this, Anisakis spp. might still represent a risk if infected fish products are served in sushi restaurants, given the low awareness related to the correct use of preventive freezing techniques of many operators demonstrated in a survey in Florence [8]. This might be the origin of the case reported by Palma et al. [89] where the source of infection was identified as raw anchovies consumed at a sushi restaurant five days before the endoscopy.

\section{Parasite detection and identification method}

To date, nine species belonging to the genus Anisakis have been identified worldwide [76]. However, only two of them, $A$. simplex (s.s.) and A. pegreffii, have been reported as responsible for infections in humans [71, 76]. Unambiguous identification of anisakids is an essential requirement for conducting epidemiological surveys [61]. In this light, more accurate diagnosis of human anisakidosis by applying sensitive, rapid and specific molecular methodologies, ideally combined with serodiagnostics such as immunoblotting, would greatly improve knowledge on anisakid epidemiology [68]. In this study, in all the 16 cases for which a molecular diagnosis was available, $A$. pegreffi $i$ was found to be the causative agent of anisakiasis. These data confirm that in the Mediterranean region, the zoonotic risk is mainly associated with the presence of this species [73, 76, 79]. In fact, $A$. pegreffii frequently occurs in various fish and squid species from the Mediterranean Sea [72] and it is the species most frequently involved in zoonotic infections in Italy [35, $68,71,74-76]$. It should be noted that the first Italian case of invasive infection with Pseudoterranova decipiens was recently described in a woman from Sicily. Unfortunately, it was not possible to clearly identify the source of infection likely due to imported infected fish. The parasite identification was confirmed by sequence analysis of mtDNA cox 2 gene [28], further highlighting the importance of pursuing molecular diagnosis.

In the cases of histological examination, the diagnosis was based on the morphological features of the nematode larva (such as the presence of polymyarian muscle cells in a transverse section, shape of the lateral chords, oesophagus with a triangular lumen). The presence of the detected larva was generally associated with an eosinophilic infiltrate or granuloma [5, 15, 26, 64, 67, 82-84, 90, 91]. Pathologists should consider the possibility of anisakid infection when facing an eosinophilic granuloma of the digestive tract, the mesentery, or the peritoneum. Several sections of the granuloma must be performed in seeking sections of the nematode, since in some cases the presence of the larva is not particularly obvious and may be overlooked [82, 90]. However, currently, it is also possible to perform molecular diagnosis on a single histological section, based on real-time PCR DNA primer-probe systems [75].

\section{Site of infection and number of larvae}

A confirmed aetiological diagnosis is based on directly finding the nematode larva in the relative organ; thus gastric anisakidosis is generally more easily detected, while the diagnosis in the case of intestinal or ectopic locations is often more challenging [62]. The present results show that in the cases included in the study, gastric and intestinal localisations had 
very similar frequencies, only slightly higher for gastric lesions. Similarly, in a retrospective case series study conducted on 83 cases in Tokyo, Japan, 47\% of patients presented gastric anisakiasis and 53\% small intestinal anisakiasis [114]. However, other authors state that in Japan, the acute gastric form prevails $(95 \%)$, while in Europe the chronic intestinal form seems to be more frequent $[82,108]$.

Beside unusual gastrointestinal localisation such as the colon, caecum and oesophagus [5, 12, 39], rarely, anisakid larvae have been found even in other extra-intestinal organs such as larynx, lungs, lymph nodes, uterus, ovaries, spleen, liver and pancreas [58, 90, 98].

In most of the cases, one larva was found, in agreement with observations of other authors [87]. It is known that one single larva can be responsible for clinical symptoms [63].

\section{Symptoms and time between the ingestion of infected food and the onset of symptoms}

Epigastric pain, frequently associated with nausea and vomiting, was the most frequently observed symptom in the present retrospective analysis, in agreement with recent studies $[110,114]$. These observations support the suggestion of some authors who consider anisakiasis as a misdiagnosed and underestimated cause of acute abdomen disorders [25]. In particular, anisakiasis should be considered when the cause of abdominal pain cannot be determined by initial assessment [114].

In general, symptoms were not specific and the co-existence of other gastroenteric disorders complicated their interpretation. In these cases, indirect serological tests (skin-prick test and specific IgE) but also non-specific parameters, when present (leucocytosis, hypersedimetry, eosinophilia), can provide useful diagnostic indications [82].

As regards symptom onset, the highly significant statistical association between the larval localisation and the time of symptom onset observed for the cases included here, with gastric cases presenting symptoms within $24 \mathrm{~h}$ from the ingestion of a food at risk, and subacute or chronic onset in extragastric locations, was observed by Takabayashi et al. [114]. Similarly, in most of the 645 Korean cases reviewed by Sohn et al. [110], of which $82.4 \%$ presented a gastric localisation, symptoms occurred within $12 \mathrm{~h}$ after raw or undercooked fish consumption.

Overall, most of the patients could recall eating raw or undercooked fish, and some of them were habitual consumers. Only in one case, the patient reported not having consumed raw fish, a fact that might be explained considering that not all consumers are aware that marinated fish should actually be considered as raw. This should be kept in mind when investigating the history $[47,114]$.

\section{Treatment and outcome}

In acute gastric forms, endoscopy represents not only a valid diagnostic tool but also the elective treatment for gastric anisakiasis [23, 114], as also observed in this retrospective study. Many reports included in the study state that the patient had a prompt recovery after removal of the worm by endo- scopy [49, 65, 117]. Also Shimamura et al. [108] observed that extraction of the larvae will usually result in prompt symptom resolution. For effective treatment, however, it is important to ensure that there is no remaining larva within the gastric wall. Thorough examination of the stomach is crucial as there is a possibility of multiple infections [87] and it is challenging to identify the larvae especially in the greater curvature [108], the most frequent parasitic location in the organ [87, 107]. For the other forms of anisakiasis, the choice of treatment depends on the specific complications [97]. Since the symptoms of anisakiasis are not pathognomonic, gastric anisakidosis is often misdiagnosed as peptic ulcer, stomach tumour or stomach polyps, while intestinal anisakidosis is often misdiagnosed as appendicitis, ileus, or peritonitis [62, 103, 114]. Pampiglione et al. [90] pointed out that the clinical diagnosis was incorrect in all the 11 cases reviewed in their study. Interestingly, in most of the cases undergoing surgery reviewed here, very often other diseases were suspected (in most of the cases appendicitis) and the diagnosis of anisakiasis was only performed after the histological examination of the sample (Appendix B).

To date, there is no definitive medicinal therapy [108]. Albendazole and ivermectin have been shown to be effective [97]. As concerns the antiparasitic treatment in the cases reviewed here, albendazole was given in one patient with colon localisation treated by endoscopy, while in 3 patients it was associated with surgery. The various compounds and dosages are reported in Appendix B. The use of antiparasitic drugs alone is controversial, since once Anisakis spp. larvae have penetrated the thickness of the intestinal wall, though subsequently killed by the drug, they can still cause an antigenic reaction, and may contribute to the development of eosinophilic granuloma [90].

\section{Occurrence of allergic reactions}

Gastrointestinal anisakiasis may be accompanied by IgE-mediated allergic reactions, ranging from urticaria or angio-oedema to anaphylaxis $[70,71,75]$. The condition of patients who develop IgE-mediated allergic reactions and gastrointestinal symptoms simultaneously is generally indicated as "gastro-allergic anisakiasis (GAA)", an acute allergic reaction with symptoms of hypersensitivity appearing several hours after the ingestion of infected, raw and/or undercooked fish, associated with penetration of larvae into the gastric mucosa [37]. In some cases, an IgE antibody response in individuals with no apparent symptoms has been detected one month after the acute GAA episode [70]. Other reports of allergic reaction related to Anisakis infections occurred without larval detection and identification of the parasite, and some patients may only present classic manifestations of IgE-mediated allergy such as urticaria, angio-oedema and anaphylaxis [50]. In fact, Anisakis spp. have also been deemed responsible for occupational allergies following skin contact or inhalation of allergens [14] and a high level of Anisakis-IgE hypersensitivity in Italian fishery products handlers, fishermen and consumers of fish was reported using the iCAP methodology [77]. However, in these patients, the presence of a larva was not detected. The sensitisation pathway is not completely understood. Anisakis 
sensitisation is most frequently reported from Mediterranean countries, Japan or South Korea and it has been associated with high consumption levels of raw or undercooked fish, since it is believed that a prior infection with live larvae is needed for sensitisation to the parasite allergens. Thus, this differential IgE sensitisation could be related to the higher consumption of raw, undercooked or marinated fish in Mediterranean countries, as opposed to the lower levels of these dishes consumed in North European countries [70].

As a consequence, the cases included in the present study, that always harboured an infective larva, could be at risk of developing sensitisation to Anisakis spp. antigens. In fact, it can be supposed that for both $A$. pegreffii and $A$. simplex (s.l.) not only live, but also non-viable larvae or related antigens could be involved in chronic urticarial reactions, despite the mechanism still needing to be discovered [70].

\section{Conclusions}

This is the first retrospective study reviewing epidemiological data and clinical manifestations of the cases of anisakiasis occurring in Italy since its first description. The number of cases of anisakiasis is certainly higher than reported, since many might not be diagnosed or published, and others might heal spontaneously. Our study suggests that human anisakiasis must be taken into account in the differential diagnosis of acute abdominal syndromes, particularly in patients who usually consume raw or undercooked fish. Furthermore, it highlights common aspects between cases and points out limits in diagnosis and treatment. These aspects may be of interest to medical doctors for managing anisakiasis in other countries.

Pathologists should take into account the possibility of this parasitic infection when examining an eosinophilic granuloma of the digestive tract, mesentery or peritoneum. Underestimating this possibility can lead to a considerable delay in diagnosis, and thus in treatment. In addition, clinicians should be encouraged to perform serodiagnosis by using appropriate diagnostic methods and to carry out and report molecular identification of the parasite, to increase knowledge about the association between different Anisakis spp. and their pathogenic effects on humans. Specific attention should also be given to the patient history in order to investigate the likely source of infection. These data are often lacking or uncertain but they are essential for better monitoring and control of food-borne parasites using risk assessment tools.

Prophylaxis is based on health education principles aiming at informing consumers on how to manage the infection risks. Adequate health education of consumers with regard to fish preparation at home is thus of the utmost importance. The results of the present review highlight that particular attention should be given to raw marinated anchovies, which are proven to be the main source of human anisakiasis in Italy. Considering the globalisation of the food supply and changes in culinary habits, as well as the possibility that traditional dishes are also consumed by tourists visiting the country, the identification of this source as a food at risk is not limited to a national level. Finally, the importance of this study is also related to the lack of similar data available in the literature.

\section{Conflict of interest}

The authors declare that they have no competing interests.

Acknowledgements. The authors wish to thank Dr. Paolo Fazii, Santo Spirito Hospital, Pescara. The research was supported by: Istituto Pasteur Italia-Fondazione Cenci Bolognetti (grant to Mattiucci S)

\section{References}

1. AESAN (Agencia Española de Seguridad Alimentaria y Nutrición). 2007. Informe del Comité Científico de la Agencia Española de Seguridad Alimentaria y Nutrición sobre medidas para reducir el riesgo asociado a la presencia de Anisakis. Revista del Comité Científico de la AESAN, 6, 59-65.

2. AFSSA (Agence Française de Sécurité Sanitaire). 2011. Data sheet on foodborne biological hazards/Anisakis spp. Pseudoterranova spp. French Agency for Food, Environmental and Occupational Health and Safety. Available at: https://www.anses. $\mathrm{fr} / \mathrm{en} / \mathrm{system} /$ files/MIC2010sa0229FiEN.pdf

3. Aloia A, Carlomagno P, Gambardella M, Schiavo M, Pasquale V. 2011. Accidental endoscopic finding of Anisakis simplex in human colon. Microbiologia Medica, 26(3), 209-211.

4. Anastasio A, Smaldone G, Cacace D, Marrone R, Voi AL, Santoro M, Cringoli G, Pozio E. 2016. Inactivation of Anisakis pegreffii larvae in anchovies (Engraulis encrasicolus) by salting and quality assessment of finished product. Food Control, 64, 115-119.

5. Andrisani G, Spada C, Petruzziello L, Costamagna G. 2014. An unusual colonic "tumour". Digestive and Liver Disease, 46(5), 477-478.

6. Angelucci G, Meloni M, Merella P, Sardu F, Madeddu S, Marrosu R, Petza F, Salati F. 2011. Prevalence of Anisakis spp. and Hysterothylacium spp. larvae inteleosts and cephalopods sampled from waters off Sardinia. Journal of Food Protection, 74, 1769-1775.

7. APROMAR (Asociación Empresarial de Acuicultura de España). 2012. Evaluación de la presencia de nematodos del genero Anisakis en los pescados de acuicultura marina espan oles. Informe final. Available at: http://www.apromar.es/ProyectoAnisakis/APROMAR-Informe-ANISAKIS-2012.pdf

8. Armani A, D'Amico P, Cianti L, Pistolesi M, Susini F, Guarducci M, Guidi A. 2017. Assessment of food business operator training on parasitological risk management in sushi restaurants: a local survey in Florence, Italy. Journal of Environmental Health, 80(2), E1.

9. Armani A, Tinacci L, Lorenzetti R, Benvenuti A, Susini F, Gasperetti L, Ricci E, Guarducci M, Guidi A. 2017. Is raw better? A multiple DNA barcoding approach (full and mini) based on mitochondrial and nuclear markers reveals low rates of misdescription in sushi products sold on the Italian market. Food Control, 79, 126-133.

10. Audicana MT, Ansotegui IJ, de Corres LF, Kennedy MW. 2002. Anisakis simplex: dangerous - dead and alive? Trends in Parasitology, 18(1), 20-25.

11. Audicana MT, Kennedy MW. 2008. Anisakis simplex: from obscure infectious worm to inducer of immune hypersensitivity. Clinical Microbiology Reviews, 21(2), 360-379.

12. Avellino P, Farjallah S, Di Giulio E, Farina C, Milione M, Cipriani P, Modiano D, D’Amelio S. 2007. Diagnosi di un caso di anisakidosi esofagea mediante PCR-RFLP. Microbiologia Medica, 22(3), 226. 
13. Bao M, Pierce GJ, Pascual S, González-Muñoz M, Mattiucci S, Mladineo I, Cipriani P, Bušelić I, Strachan NJ. 2017. Assessing the risk of an emerging zoonosis of worldwide concern: anisakiasis. Scientific Reports, 7, 43699.

14. Barbuzza O, Guarneri F, Galtieri G, Gangemi S, Vaccaro M. 2009. Protein contact dermatitis and allergic asthma caused by Anisakis simplex. Contact Dermatitis, 60, 239-240.

15. Baron L, Branca G, Trombetta C, Punzo E, Quarto F, Speciale G, Barresi V. 2014. Intestinal anisakidosis: histopathological findings and differential diagnosis. Pathology-Research and Practice, 210(11), 746-750.

16. Bavastrelli M, Riccardo F, Binazzi R, Sanguigni S. 2001. Small intestine anisakiasis. Giornale Italiano di Medicina Tropicale, 6(1-2), 49-50.

17. Beaudry C. 2012. Bad bug book: Foodborne pathogenic microorganisms and natural toxins handbook, 2nd edn., Center for Food Safety and Applied Nutrition, U.S. Food and Drug Administration: Washington, DC.

18. Biondi G, Basili G, Lorenzetti L, Prosperi V, Angrisano C, Gentile V, Goletti O. 2008. Addome acuto da anisakidosi ileale. Chirurgia Italiana, 60, 623-626.

19. Bruschi F. 2009. How parasitology is taught in medical faculties in Europe? Parasitology, lost? Parasitology Research, 105(6), 1759.

20. Bruschi F, Gómez-Morales MA. 2017. Parasites, in Foodborne diseases, 3rd edn., Dodd CER, Aldsworth T, Stein RA, Cliver DO, Riemann HP, Editors. Academic Press: London, UK, p. 305-324.

21. Bucci C, Gallotta S, Morra I, Fortunato A, Ciacci C, Iovino P. 2013. Anisakis, just think about it in an emergency! International Journal of Infectious Diseases, 17(11), e1071-e1072.

22. Bušelić I, Botić A, Hrabar J, Stagličić N, Cipriani P, Mattiucci S, Mladineo I. 2018. Geographic and host size variations as indicators of Anisakis pegreffii infection in European pilchard (Sardina pilchardus) from the Mediterranean Sea: food safety implications. International Journal of Food Microbiology, 266, 126132.

23. Cancrini G, Macri G, Ridolfi G. 1998. Caso di anisakiosi gastrica in Sicilia, diagnosticato e risolto mediante endoscopia. Parassitologia, 40(Suppl 1), 26.

24. Cancrini G, Magro G, Giannone G. 1997. Primo caso di anisakiosi extragastrointestinale nell'uomo diagnosticato in Italia. Parassitologia, 39(1), 13-17.

25. Caramello P, Vitali A, Canta F, Caldana A, Santi F, Caputo A, Lipani F, Balbiano R. 2003. Intestinal localization of anisakiasis manifested as acute abdomen. Clinical Microbiology and Infection, 9(7), 734-737.

26. Carbotta G, Laforgia R, Milella M, Sederino MG, Minafra M, Fortarezza F, Piscitelli D, Palasciano N. 2016. Small bowel obstruction caused by Anisakis and Meckel's diverticulum: a rare case. Il Giornale di Chirurgia, 37(6), 281.

27. Cavallero S, Magnabosco C, Civettini M, Boffo L, Mingarelli G, Buratti P, Giovanardi O, Fortuna CM, Arcangeli G. 2015. Survey of Anisakis sp. and Hysterothylacium sp. in sardines and anchovies from the North Adriatic Sea. International Journal of Food Microbiology, 200, 18-21.

28. Cavallero S, Scribano D, D'Amelio S. 2016. First case report of invasive pseudoterranoviasis in Italy. Parasitology International, 65(5), 488-490.

29. Cesaro P, Petruzziello L, Spada C, Costamagna G. 2013. Intestinal occlusion-like syndrome caused by anisakiasis of the small bowel: case report, inAtlas of ileoscopy: a collection of clinical cases, Trecca A, Editor. Springer: Milano, Italy. p. 71-74.

30. Chai JY, Murrell KD, Lymbery AJ. 2005. Fish-borne parasitic zoonoses: status and issues. International Journal of Parasitology, 35, 1233-1254.
31. Chaligiannis I, Lalle M, Pozio E, Sotiraki S. 2012. Anisakidae infection in fish of the Aegean Sea. Veterinary Parasitology, 184, 362-366.

32. Cipriani P, Acerra V, Bellisario B, Sbaraglia GL, Cheleschi R, Nascetti G, Mattiucci S. 2016. Larval migration of the zoonotic parasite Anisakis pegreffii (Nematoda: Anisakidae) in European anchovy, Engraulis encrasicolus: implications to seafood safety. Food Control, 59, 148-157.

33. Cipriani P, Sbaraglia GL, Paoletti M, Giulietti L, Bellisario B, Bušelić I, Mladineo I, Cheleschi R, Nascetti G, Mattiucci S. 2018. Anisakis pegreffii (Nematoda: Anisakidae) in European anchovy Engraulis encrasicolus from the Mediterranean Sea: Fishing ground as a predictor of parasite distribution. Fisheries Research, 202, 59-68.

34. Colombo F, Cattaneo P, Castelletti M, Bernardi C. 2016. Prevalence and mean intensity of Anisakidae parasite in seafood caught in Mediterranean Sea focusing on fish species at risk of being raw-consumed. A meta-analysis and systematic review. Critical Reviews in Food Science and Nutrition, 56, $1405-1416$.

35. D'Amelio S, Mathiopoulos KD, Brandonisio O, Lucarelli G, Doronzo F, Paggi L. 1999. Diagnosis of a case of gastric anisakidosis by PCR-based restriction fragment length polymorphism analysis. Parassitologia, 41(4), 591-593.

36. D'Amico P, Malandra R, Costanzo F, Castigliego L, Guidi A, Gianfaldoni D, Armani A. 2014. Evolution of the Anisakis risk management in the European and Italian context. Food Research International, 64, 348-362.

37. Daschner A, Alonso-Gómez A, Cabañas R, Suarez-de-Parga JM, López-Serrano MC. 2000. Gastroallergic anisakiasis: borderline between food allergy and parasitic disease-clinical and allergologic evaluation of 20 patients with confirmed acute parasitism by Anisakis simplex. Journal of Allergy and Clinical Immunology, 105, 176-181.

38. De Liberato C, Bossù T, Scaramozzino P, Nicolini G, Ceddia P, Mallozzi S, Cavallero S, D'Amelio S. 2013. Presence of anisakid larvae in the European anchovy, Engraulis encrasicolus, fished off the Tyrrhenian coast of central Italy. Journal of Food Protection, 76(9), 1643-1648.

39. De Nicola P, Napolitano LM, Di Bartolomeo N, Waku M, Innocenti P. 2005. Su di un caso di anisachiasi con perforazione del cieco. Il Giornale di Chirurgia, 26(10), 375-377.

40. De Rosa C. 2011. Una parassitosi emergente: l'Anisakiasi. Degree thesis. University of Chieti - Pescara.

41. Dorny P, Praet N, Deckers N, Gabriel S. 2009. Emerging foodborne parasites. Veterinary Parasitology, 163(3), 196-206.

42. EFSA (European Food Safety Authority). 2017. European Union summary report on trends and sources of zoonoses, zoonotic agents and food-borne outbreaks in 2016. Available at: https://www.efsa.europa.eu/en/efsajournal/pub/5077

43. EFSA (European Food Safety Authority). 2010. Scientific opinion on risk assessment of parasites in fishery products and EFSA Panel on Biological Hazards (BIOHAZ). EFSA Journal, $8,1543$.

44. FAO/WHO (Food and Agriculture Organization of the United Nations/World Health Organization). 2014. Multicriteria-based ranking for risk management of food-borne parasites. Microbiological Risk Assessment Series, Series No. 23, Rome, Italy, 324 pp. Available at: http://www.fao.org/publications/card/en/c/ ee07c6ae-b86c-4d5f-915c-94c93ded7d9e/

45. Fava G, Mosca P, Germani U, Tarsetti F, Marini F, Marmorale C, Giangiacomi M, Novelli G, Lorenzini I. 2012. Acute upper gastrointestinal bleeding caused by Anisakis: a case report. Digestive and Liver Disease, 44, 94-95.

46. Fayer R. 2015. Introduction and Public Health Importance of Foodborne Parasites, in Biology of Foodborne Parasites. Xiao 
L, Ryan U, Feng Y, Editors. Food Microbiology Series, CRC Press, Taylor and Francis Group: London \& New York, p. 3-20.

47. Fazii P, Neri M, Bucci E, Pistola F, Laterza F, Colagrande E, Cosentino L, Caldarella MP, Clerico L, Stella M, Pelatti A, Riaro-Sforza G. 2006. Diagnosi e terapia dell'anisakidosi mediante endoscopio. Descrizione di tre casi in abruzzo. Microbiologia Medica, 21(3).

48. Filauro M, Rollandi GA, Cassola G, Quilici P, Angelini G, Belli F, Boccardo C. 2011. Gastrointestinal bleeding due to suspected anisakiasis: challenging differential diagnosis for a rare disease. Updates in Surgery, 63(3), 213-217.

49. Fumarola L, Monno R, Ierardi E, Rizzo G, Giannelli G, Lalle M, Pozio E. 2009. Anisakis pegreffi etiological agent of gastric infections in two Italian women. Foodborne Pathogens and Disease, 6(9), 1157-1159.

50. Gallo R, Cecchi F, Parodi A. 2012. Intractable chronic pruritus as the only manifestation of IgE hypersensitivity to Anisakis. Journal of the American Academy of Dermatology, 67(6), e261.

51. Griglio B, Marro S, Marotta V, Testa A, Sattanino G, Civera T, Fazio G, Negro M, Cravero M, Pairone B, Raschio C, Rossignoli M, Biglia C, Raschio C. 2012. Anisakidae: valutazione del rischio e indicazioni operative per i controlli ufficiali alla luce del quadro normativo. AIVEMP News, 4, 7-20.

52. Guardone L, Nucera D, Lodola LB, Tinacci L, Acutis PL, Guidi A, Armani A. 2018. Anisakis spp. larvae in different kinds of ready to eat products made of anchovies (Engraulis encrasicolus) sold in Italian supermarkets. International Journal of Food Microbiology, 268, 10-18.

53. Guardone L, Nucera D, Pergola V, Costanzo F, Costa E, Tinacci L, Guidi A, Armani A. 2017. Visceral larvae as a predictive index of the overall level of fish batch infection in European anchovies (Engraulis encrasicolus): a rapid procedure for Food Business Operators to assess marketability. International Journal of Food Microbiology, 250, 12-18.

54. Hubert B, Bacou J, Belveze H. 1989. Epidemiology of human anisakiasis: incidence and sources in France. American Journal of Tropical Medicine and Hygiene, 40, 301-303.

55. Ioli A, Leonaldi R, Gangemi C, Giudice LL, Bottari M, Petithory JC. 1998. A propos d'un cas d'anisakiase contractée en Sicile. Bulletin de la Société de Pathologie Exotique et de ses Filiales, 91, 232-234.

56. Karl H, Roepstor A, Huss HH, Bloemsma B. 1994. Survival of Anisakis larvae in marinated herring fillets. International Journal of Food Science and Technology, 29(6), 661-670.

57. Kassai T, Del Campillo MC, Euzeby J, Gaafar S, Hiepe T, Himonas CA. 1988. Standardized nomenclature of animal parasitic diseases (SNOAPAD). Veterinary Parasitology, 29(4), 299-326.

58. Kwak SY, Yoon YH. 2012. Laryngeal Anisakiasis an unusual cause of foreign-body sensation in the throat. Otolaryngology Head and Neck Surgery, 147(3), 588-589.

59. Legislative Decree 17th July 2013- Informazioni obbligatorie a tutela del consumatore di pesce e cefalopodi freschi e di prodotti di acqua dolce, in attuazione dell'articolo 8, comma 4, del decreto-legge 13 settembre 2012 n. 158, convertito, con modificazioni, dalla legge 8 novembre 2012, n. 189. G.U. del 20 agosto 2013, n. 187.

60. Levsen A, Svanevik CS, Cipriani P, Mattiucci S, Gay M, Hastie LC, Bušelić I, Mladineo I, Karl H, Ostermeyer U, Buchmann K, Højgaard DP, Gonzáles A, Pascual S, Piercee GJ. 2018. A survey of zoonotic nematodes of commercial key fish species from major European fishing grounds - introducing the FP7 PARASITE exposure assessment study. Fisheries Research, 202, 4-21.

61. Lim H, Jung BK, Cho J, Yooyen T, Shin EH, Chai JY. 2015. Molecular diagnosis of cause of anisakiasis in humans, South Korea. Emerging Infectious Diseases, 21(2), 342.
62. Lymbery AJ, Cheah FY. 2007. Anisakid Nematodes and Anisakiasis, in Food-borne parasitic zoonoses. Fish and PlantBorne Parasites. Murrell KD, Fried B, Editors. Springer: New York, p. 185-208.

63. Madrid E, Galán-Puchades MT, Fuentes MV. 2012. Risk analysis of human anisakidosis through the consumption of the blue whiting, Micromesistius poutassou, sold at Spanish supermarkets. Foodborne Pathogens and Disease, 9(10), 934-938.

64. Maggi P, Caputi-Iambrenghi O, Scardigno A, Scoppetta L, Saracino A, Valente M, Pastore G, Angarano G. 2000. Gastrointestinal infection due to Anisakis simplex in southern Italy. European Journal of Epidemiology, 16(1), 75-78.

65. Mariano E, Fioranelli M, Roccia MG, Onorato M, Di Nardo V, Bianchi M. 2015. Anedoctodal report of acute gastric anisakiasis and severe chest discomfort. Journal of Integrative Cardiology, 1(6), 210-212.

66. Marra D, Travaglini G, Fianchini A, Marmorale C. 2013. A case of bleeding gastric lesion: a diagnosis to keep in mind. Journal of Gastroenterology and Hepatology Research, 2(2), 423-425.

67. Marzocca G, Rocchi B, Gatto ML, Polito S, Varrone F, Caputo E, Sorbellini F. 2009. Addome acuto da Anisakiasi e globalizzazione. Annali Italiani di Chirurgia, 80(1), 65-68.

68. Mattiucci S, Cipriani P, Paoletti M, Levsen A, Nascetti G. 2017. Reviewing biodiversity and epidemiological aspects of anisakid nematodes from the north-East Atlantic Ocean. Journal of Helminthology, 91(4), 422-439.

69. Mattiucci S, Cipriani P, Webb SC, Paoletti M, Marcer F, Bellisario B, Gibson DI, Nascetti G. 2014. Genetic and morphological approaches distinguishing the three sibling species of the Anisakis simplex species complex, with a species designation as Anisakis berlandi n. sp. for A. simplex sp. C (Nematoda: Anisakidae). Journal of Parasitology, 15, 12.

70. Mattiucci S, Colantoni A, Crisafi B, Mori-Ubaldini F, Caponi L, Fazii P, Nascetti P, Bruschi F. 2017. IgE sensitization to Anisakis pegreffii in Italy: comparison of two methods for the diagnosis of allergic anisakiasis. Parasite Immunology, 9, e12440.

71. Mattiucci S, Fazii P, De Rosa A, Paoletti M, Salomone Megna A, Glielmo A, De Angelis M, Costa A, Meucci C, Calvaruso V, Sorrentini I, Palma G, Bruschi F, Nascetti G. 2013. Anisakiasis and gastroallergic reactions associated with Anisakis pegreffii infection, Italy. Emerging Infectious Diseases, 19(3), 496-499.

72. Mattiucci S, Nascetti G. 2006. Molecular systematics, phylogeny and ecology of anisakid nematodes of the genus Anisakis Dujardin, 1845: an update. Parasite, 13, 99-113.

73. Mattiucci S, Nascetti G. 2008. Advances and trends in the molecular systematics of anisakid nematodes, with Implications for their evolutionary ecology and host-parasite co-evolutionary processes. Advances in Parasitology, 66, 47148.

74. Mattiucci S, Paoletti M, Borrini F, Palumbo M, Palmieri RM, Gomes V, Casati A, Nascetti G. 2011. First molecular identification of the zoonotic parasite Anisakis pegreffii (Nematoda: Anisakidae) in a paraffin-embedded granuloma taken from a case of human intestinal anisakiasis in Italy. BMC Infectious Diseases, 11(1), 1.

75. Mattiucci S, Paoletti M, Colantoni A, Carbone A, Gaeta R, Proietti A, Frattaroli S, Fazii P, Bruschi F, Nascetti G. 2017. Invasive anisakiasis by the parasite Anisakis pegreffii (Nematoda: Anisakidae): diagnosis by real-time PCR hydrolysis probe system and immunoblotting assay. BMC Infectious Diseases, 17(1), 530 .

76. Mattiucci S, Cipriani P, Levsen A, Paoletti M, Nascetti G. 2018. Molecular epidemiology of Anisakis and anisakiasis: an ecological and evolutionary road map. Advances in Parasitology, 99, 93-263. 
77. Mazzucco W, Lacca G, Cusimano R, Provenzani A, Costa A, Di Noto AM, Massenti MF, Leto-Barone MS, Di Lorenzo G, Vitale F. 2012. Prevalence of sensitization to Anisakis simplex among professionally exposed populations in Sicily. Archives of Environmental \& Occupational Health, 67(2), 91-97.

78. Mladineo I, Poljak V. 2014. Ecology and genetic structure of zoonotic Anisakis spp. from Adriatic commercial fish species. Applied and Environmental Microbiology, 80(4), 1281-1290.

79. Mladineo I, Popović M, Drmic-Hofman I, Poljak V. 2016. A case report of Anisakis pegreffii (Nematoda, Anisakidae) identified from archival paraffin sections of a Croatian patient. BMC Infectious Diseases, 16, 42.

80. Mladineo I, Šimat V, Miletić J, Beck R, Poljak V. 2012. Molecular identification and population dynamic of Anisakis pegreffii (Nematoda: Anisakidae Dujardin, 1845) isolated from the European anchovy (Engraulis encrasicolus L.) in the Adriatic Sea. International Journal of Food Microbiology, 157(2), 224-229.

81. Molina-Fernández D, Malagón D, Gómez-Mateos $\mathrm{M}$, Benítez R, Martín-Sánchez J, Adroher FJ. 2015. Fishing area and fish size as risk factors of Anisakis infection in sardines (Sardina pilchardus) from Iberian waters, southwestern Europe. International Journal of Food Microbiology, 203, 27-34.

82. Montalto M, Miele L, Marcheggiano A, Santoro L, Curigliano V, Vastola M, Gasbarrini G. 2005. Anisakis infestation: a case of acute abdomen mimicking Crohn's disease and eosinophilic gastroenteritis. Digestive and Liver Disease, 37(1), 62-64.

83. Moschella CM, Mattiucci S, Mingazzini P, De Angelis G, Assenza M, Lombardo F, Monaco S, Paggi L, Modini C. 2004. Intestinal anisakiasis in Italy: case report. Journal of Helminthology, 78(03), 271-273

84. Mumoli N, Merlo A. 2013. Colonic anisakiasis. Canadian Medical Association Journal, 185(13), 652-652.

85. Murrell KD, Fried B. 2007. Food-borne parasitic zoonoses. Fish and plant-borne parasites. New York: Springer Science \& Business Media.

86. Nawa Y, Hatz C, Blum J. 2005. Sushi delights and parasites: the risk of fishborne and foodborne parasitic zoonoses in Asia. Clinical Infectious Diseases, 41(9), 1297-1303.

87. Noh JH, Kim BJ, Kim SM, Ock MS, Park MI, Goo JY. 2003. A case of acute gastric anisakiasis provoking severe clinical problems by multiple infection. Korean Journal of Parasitology, 41(2), 97-100.

88. Orphanet. 2016. Prevalence and incidence of rare diseases: Bibliographic data. Orphanet Report Series, 1. Available at: http://www.orpha.net/orphacom/cahiers/docs/GB/Prevalence_ of_rare_diseases_by_alphabetical_list.pdf

89. Palma R, Mattiucci S, Panetta C, Raniolo M, Magliocca FM, Pontone S. 2018. Paucisymptomatic gastric anisakiasis: endoscopical removal of Anisakis sp. larva. Mini-Invasive Surgery, 2, 1

90. Pampiglione S, Rivasi F, Criscuolo M, De Benedittis A, Gentile A, Russo S, Testini M, Villani M. 2002. Human anisakiasis in Italy: a report of eleven new cases. PathologyResearch and Practice, 198(6), 429-434.

91. Pellegrini M, Occhini R, Tordini G, Vindigni C, Russo S, Marzocca G. 2005. Acute abdomen due to small bowel anisakiasis. Digestive and Liver Disease, 37(1), 65-67.

92. Peñalver J, Dolores EM, Muñoz P. 2010. Absence of anisakid larvae in farmed European sea bass (Dicentrarchus labrax L.) and gilthead sea bream (Sparus aurata L.) in Southeast Spain. Journal of Food Protection, 73(7), 1332-1334.

93. Pezzilli R, Casadei R, Santini D. 2007. Autoimmune pancreatitis associated with anisakis infection. Digestive and Liver Disease, 39(3), 273.
94. Piras MC, Tedde T, Garippa G, Virgilio S, Sanna D, Farjallah S, Merella P. 2014. Molecular and epidemiological data on Anisakis spp. (Nematoda: Anisakidae) in commercial fish caught off northern Sardinia (western Mediterranean Sea) Veterinary Parasitology, 203(1-2), 237-240.

95. Piscaglia AC, Ventura MT, Landolfo G, Giordano M, Russo S, Landi R, Zulian V, Forte F, Stefanelli ML. 2014. Chronic anisakidosis presenting with intestinal intussusception. European Review for Medical and Pharmacological Sciences, 18(24), 3916-3920.

96. Pontone S, Leonetti G, Guaitoli E, Mocini R, Manfredelli S, Catania A, Pontone P, Sorrenti S. 2012. Should the host reaction to anisakiasis influence the treatment? Different clinical presentations in two cases. Revista Española de Enfermedades Digestivas, 104(11), 607-610.

97. Pozio E. 2013. Integrating animal health surveillance and food safety: the example of Anisakis. Revue scientifique et technique (International Office of Epizootics), 32(2), 487-496.

98. Ramanan P, Blumberg AK, Mathison B, Pritt BS. 2013. Parametrial anisakidosis. Journal of Clinical Microbiology, 51(10), 3430-3434.

99. Rea R, Di Matteo F, Scarpa F, Pandolfi M, Martino M, Dicuonzo G, Gabbrielli A. 2008. Identification and removal of an Anisakis in acute gastric anisakiasis. Digestive and Liver Disease, 40, 73

100. Rello FJ, Adroher FJ, Benítez R, Valero A. 2009. The fishing area as a possible indicator of the infection by anisakids in anchovies (Engraulis encrasicolus) from southwestern Europe. International Journal of Food Microbiology, 129, 277-281.

101. Riva G, Manfredi MT, Intino C. 2000. Serological diagnosis of human infection by Anisakis simplex. Parassitologia, 42, 222.

102. Rodríguez H, González ÁF, Abollo E, Pascual S. 2018. Re-evaluation of anchovies (Engraulis encrasicolus) as an important risk factor for sensitization to zoonotic nematodes in Spain. Fisheries Research, 202, 49-58.

103. Sakanari JA, McKerrow JH. 1989. Anisakiasis. Clinical Microbiology Reviews, 2, 278-284.

104. Sánchez-Alonso I, Carballda-Sangiao N, González-Muñoz M, Navas A, Arcos SC, Mendizábal A, Tejada M, Careche M. 2018. Pathogenic potential of Anisakis L3 after freezing in domestic freezers. Food Control, 84, 61-69.

105. Sánchez-Monsalvez I, de Armas-Serra C, Martinez J, Dorado M, Sanchez A, Rodriguez-Caabeiro F. 2005. A new procedure for marinating fresh anchovies and ensuring the rapid destruction of Anisakis larvae. Journal of Food Protection, 68, 1066-1072.

106. Serracca L, Battistini R, Rossini I, Carducci A, Verani M, Prearo M, Tomei L, De Montis G, Ercolini C. 2014. Food safety considerations in relation to Anisakis pegreffii in anchovies (Engraulis encrasicolus) and sardines (Sardina pilchardus) fished off the Ligurian Coast (Cinque Terre National Park, NW Mediterranean). International Journal of Food Microbiology, 190, 79-83.

107. Shibata O, Uchida Y, Furusawa T. 1989. Acute gastric anisakiasis with special analysis of the location of the worms penetrating the gastric mucosa, in Gastric anisakiasis in Japan. Epidemiology, Diagnosis, Treatment. Ishikura H, Manik M, Editors. Springer-Verlag: Tokyo, Japan, p. 53-57.

108. Shimamura Y, Muwanwella N, Chandran S, Kandel G, Marcon N. 2016. Common symptoms from an uncommon infection: gastrointestinal anisakiasis. Canadian Journal of Gastroenterology and Hepatology, 2016, 1-8.

109. Šimat V, Miletić J, Bogdanović T, Poljak V, Mladineo I. 2015. Role of biogenic amines in the post-mortem migration of Anisakis pegreffii (Nematoda: Anisakidae Dujardin, 1845) 
larvae into fish fillets. International Journal of Food Microbiology, 214, 179-186.

110. Sohn WM, Na BK, Kim TH, Park TJ. 2015. Anisakiasis: report of 15 gastric cases caused by Anisakis Type I larvae and a brief review of Korean anisakiasis cases. Korean Journal of Parasitology, 53(4), 465.

111. Sola D, Antonelli S, Federici C. 2011. Descrizione di un caso clinico e considerazioni di ordine igienico-sanitario. La Professione Veterinaria, 25, 10.

112. Sospedra I, Rubert J, Soriano JM, Mañes J, Fuentes MV. 2015. Prevalence of bacteria and absence of anisakid parasites in raw and prepared fish and seafood dishes in Spanish restaurants. Journal of Food Protection, 78(3), 615-618.

113. Stallone O, Paggi L, Balestrazzi A, Mattiucci S, Montinari M. 1996. Gastric anisakiasis in Italy: case report. Mediterranean Journal of Surgical Medicine, 4, 13-16.

114. Takabayashi T, Mochizuki T, Otani N, Nishiyama K, Ishimatsu S. 2014. Anisakiasis presenting to the ED: clinical manifestations, time course, hematologic tests, computed tomographic findings, and treatment. American Journal of Emergency Medicine, 32(12), 1485-1489.

115. Taranto D, Sessa G, Tortora R, Tremolaterra F. 2011. Narrow band imaging enhancement could improve gastric anisakis detection. Digestive and Liver Disease, 43(3), e5.

116. Testini M, Gentile A, Lissidini G, Di Venere B, Pampiglione S. 2003. Splenic anisakiasis resulting from a gastric perfora- tion: an unusual occurrence. International Surgery, 88(3), 126128.

117. Ugenti I, Lattarulo S, Ferrarese F, De Ceglie A, Manta R, Brandonisio O. 2007. Acute gastric anisakiasis: an Italian experience. Minerva Chirurgica, 62(1), 51-60.

118. Van Thiel FH, Kuipers FC, Roskam RT. 1960. A nematode parasitic to herring, causing acute abdominal syndromes in man. Tropical and Geographical Medicine, 2, 97-113.

119. Yera H, Fréalle E, Dutoit E, Dupouy-Camet J. 2018. A national retrospective survey of anisakidosis in France (2010 2014): decreasing incidence, female predominance, and emerging allergic potential. Parasite, 25, 23.

120. Zanelli M, Ragazzi M, Fiorino S, Foroni M, Cecinato P, Sanchez MDMJ, Ascani S, De Marco L. 2017. An Italian case of intestinal anisakiasis with a presurgical diagnosis: Could this parasite represent an emerging disease? PathologyResearch and Practice, 213(5), 558-564.

121. Zippi M, De Nitto D, Grassi G, Febbraro I. 2016. Small bowel occlusion due to Anisakis infection. International Journal of Case Reports and Images, 7(9), 622-623.

122. Zullo A, Hassan C, Scaccianoce G, Lorenzetti R, Campo SM, Morini S. 2010. Gastric anisakiasis: do not forget the clinical history. Journal of Gastrointestinal Liver Diseases, 19(4), 359-359.

Cite this article as: Guardone L, Armani A, Nucera D, Costanzo F, Mattiucci S \& Bruschi F. 2018. Human anisakiasis in Italy: a retrospective epidemiological study over two decades. Parasite 25, 41.

\section{PARASTE}

An international open-access, peer-reviewed, online journal publishing high quality papers on all aspects of human and animal parasitology

Reviews, articles and short notes may be submitted. Fields include, but are not limited to: general, medical and veterinary parasitology; morphology, including ultrastructure; parasite systematics, including entomology, acarology, helminthology and protistology, and molecular analyses; molecular biology and biochemistry; immunology of parasitic diseases; host-parasite relationships; ecology and life history of parasites; epidemiology; therapeutics; new diagnostic tools.

All papers in Parasite are published in English. Manuscripts should have a broad interest and must not have been published or submitted elsewhere. No limit is imposed on the length of manuscripts.

Parasite (open-access) continues Parasite (print and online editions, 1994-2012) and Annales de Parasitologie Humaine et Comparée (1923-1993) and is the official journal of the Société Française de Parasitologie. 


\section{Appendix A}

Bibliographic research to identify cases of anisakiasis

\begin{tabular}{|c|c|c|c|c|}
\hline & $\begin{array}{l}\text { PubMed } \\
\text { retrieved }\end{array}$ & $\begin{array}{l}\text { PubMed selected for } \\
\text { screening }\end{array}$ & $\begin{array}{l}\text { Google Scholar } \\
\text { retrieved }\end{array}$ & $\begin{array}{c}\text { Google Scholar selected for } \\
\text { screening }\end{array}$ \\
\hline $\begin{array}{l}\text { Anisakidae and (human or human cases) and } \\
\text { Italy }\end{array}$ & 16 & 2 & 536 & 17 \\
\hline $\begin{array}{l}\text { Anisakis and (human or human cases) and } \\
\text { Italy }\end{array}$ & 60 & 23 & 1420 & 32 \\
\hline Human anisakidosis and Italy & 7 & 4 & 320 & 26 \\
\hline Human anisakiasis and Italy & 41 & 22 & 1630 & 33 \\
\hline $\begin{array}{l}\text { (Human anisakidosis or human anisakiasis) } \\
\text { and Italy }\end{array}$ & 43 & 24 & 315 & 25 \\
\hline $\begin{array}{l}\text { Human anisakidosis or human anisakiasis } \\
\text { and Italy }\end{array}$ & 111 & 27 & 315 & 25 \\
\hline
\end{tabular}

\section{Appendix B}

Details of the data collected from the included cases. 


\begin{tabular}{|c|c|c|c|c|c|c|c|c|c|c|}
\hline Reference & Sex & Age & $\begin{array}{l}\text { Geographical } \\
\text { origin }\end{array}$ & $\begin{array}{l}\text { Source of infection and } \\
\text { time between consumption and } \\
\text { symptoms insurgence }\end{array}$ & $\begin{array}{l}\text { Parasite } \\
\text { species }\end{array}$ & $\begin{array}{l}\text { Method used fo } \\
\text { larval detection }\end{array}$ & $\begin{array}{l}\text { r Identification } \\
\text { method }\end{array}$ & $\begin{array}{l}\text { Parasite } \\
\text { location }\end{array}$ & Symptoms & Treatment/outcome \\
\hline $\begin{array}{l}\text { Stallone et al. } \\
{[113]}\end{array}$ & $\mathrm{F}$ & 40 & Apulia, Bari & $\begin{array}{l}\text { Raw fish products consumed } \\
\text { a few hours before }\end{array}$ & Anisakis sp. & n.a. & microscopy & Gastric & Epigastric pain & n.a./n.a \\
\hline Cancrini et al. & $\mathrm{F}$ & 38 & Sicily, Catania & $\begin{array}{l}\text { Habitual consumption of raw } \\
\text { fish products }\end{array}$ & Anisakis sp. & Laparatomy & Histology & Omentum & $\begin{array}{l}\text { Severe pain in the } \\
\text { ileocecal region }\end{array}$ & Surgery/n.a. \\
\hline $\begin{array}{l}\text { Cancrini et al. } \\
\text { [23] }\end{array}$ & M & 50 & Sicily, Catania & $\begin{array}{l}\text { Raw fish ("pesce azzurro") } \\
\text { consumed } 10 \mathrm{~h} \text { before }\end{array}$ & Anisakis sp. & Endoscopy & Microscopy & Gastric & Acute epigastric pain & $\begin{array}{l}\text { Removal by } \\
\text { endoscopy/n.a. }\end{array}$ \\
\hline $\begin{array}{l}\text { D'Amelio et al. } \\
\text { [35] }\end{array}$ & $\mathrm{F}$ & 51 & Apulia, Bari & $\begin{array}{l}\text { Habitual consumption of } \\
\text { raw fish and squids }\end{array}$ & A. pegreffii & Endoscopy & PCR-RFLPs & Gastric & $\begin{array}{l}\text { Acute severe epigastralgia, } \\
\text { followed } 20 \text { days later } \\
\text { by generalized urticaria, } \\
\text { neck and head } \\
\text { paresthesia }\end{array}$ & $\begin{array}{l}\text { Removal by } \\
\text { endoscopy/n.a. }\end{array}$ \\
\hline \multirow[t]{3}{*}{$\begin{array}{l}\text { Maggi et al. } \\
{[64]}\end{array}$} & $\mathrm{F}$ & 43 & Apulia & $\begin{array}{l}\text { Unclear, raw fish normally } \\
\text { consumed }\end{array}$ & A. simplex & Laparatomy & Histology & Gastric & Epigastric pain & $\begin{array}{l}\text { Surgery/no } \\
\text { complications }\end{array}$ \\
\hline & $\mathrm{F}$ & 34 & Apulia & Non-consumer of raw fish & A. simplex & Laparatomy & Histology & Ileum & Abdominal pain & $\begin{array}{l}\text { Surgery/no } \\
\text { complications }\end{array}$ \\
\hline & $\mathrm{F}$ & 43 & Apulia & $\begin{array}{l}\text { Pickled anchovies normally } \\
\text { consumed }\end{array}$ & A. simplex & Laparatomy & Histology & $\begin{array}{l}\text { Jejunal } \\
\text { mesentery }\end{array}$ & Abdominal cramps & $\begin{array}{l}\text { Surgery }+ \\
\text { mebendazole }(200 \\
\mathrm{mg} / \text { day in } 2 \text { doses } \\
\text { for } 3 \text { days }) / \text { follow } \\
\text { up in progress }\end{array}$ \\
\hline \multirow[t]{7}{*}{$\begin{array}{l}\text { Pampiglione } \\
\text { et al. [90] }\end{array}$} & $\mathrm{F}$ & 30 & Apulia, Bari & $\begin{array}{l}\text { Raw marinated sardines or } \\
\text { anchovies occasionally } \\
\text { consumed }\end{array}$ & Anisakis sp. & Laparatomy & Histology & Ileum & $\begin{array}{l}\text { Acute abdominal } \\
\text { syndrome }\end{array}$ & Surgery/n.a. \\
\hline & $\mathrm{F}$ & 22 & $\begin{array}{l}\text { Molise, } \\
\text { Campobasso }\end{array}$ & $\begin{array}{l}\text { Raw marinated sardines or } \\
\text { anchovies consumed a } \\
\text { few days before }\end{array}$ & Anisakis sp. & Laparatomy & Histology & Mesentery & Acute appendicitis & Surgery/n.a. \\
\hline & $\mathrm{F}$ & 54 & Apulia, Bari & $\begin{array}{l}\text { raw marinated sardines or } \\
\text { anchovies consumed a } \\
\text { few days before }\end{array}$ & Anisakis sp. & Laparatomy & Histology & Omentum & Intestinal occlusion & Surgery/n.a. \\
\hline & M & 37 & Apulia, Bari & $\begin{array}{l}\text { Raw marinated sardines or } \\
\text { anchovies occasionally } \\
\text { consumed }\end{array}$ & Anisakis sp. & Laparatomy & Histology & Omentum & Gastric ulcer & Surgery/n.a. \\
\hline & $\mathrm{F}$ & 44 & $\begin{array}{l}\text { Molise, } \\
\text { Campobasso }\end{array}$ & $\begin{array}{l}\text { Raw marinated sardines or } \\
\text { anchovies consumed } \\
4 \text { days before }\end{array}$ & Anisakis sp. & Laparatomy & Histology & Omentum & Intestinal occlusion & Surgery/n.a. \\
\hline & $\mathrm{F}$ & 60 & Apulia, Bari & $\begin{array}{l}\text { Raw marinated sardines or } \\
\text { anchovies habitually } \\
\text { consumed }\end{array}$ & Anisakis sp. & Laparatomy & Histology & $\begin{array}{l}\text { Epiploic } \\
\text { appendix }\end{array}$ & Colon neoplasia & Surgery/n.a. \\
\hline & M & 48 & Apulia, Brindisi & $\begin{array}{l}\text { i Raw marinated sardines or } \\
\text { anchovies consumed } 8 \mathrm{~h} \\
\text { before }\end{array}$ & Anisakis sp. & Laparatomy & Histology & Ileum & Intestinal occlusion & Surgery/n.a. \\
\hline
\end{tabular}




\begin{tabular}{|c|c|c|c|c|c|c|c|c|c|c|}
\hline Reference & Sex & Age & $\begin{array}{l}\text { Geographical } \\
\text { origin }\end{array}$ & $\begin{array}{l}\text { Source of infection and } \\
\text { time between consumption and } \\
\text { symptoms insurgence }\end{array}$ & $\begin{array}{l}\text { Parasite } \\
\text { species }\end{array}$ & $\begin{array}{l}\text { Method used for } \\
\text { larval detection }\end{array}$ & $\begin{array}{l}\text { r Identification } \\
\text { method }\end{array}$ & $\begin{array}{l}\text { Parasite } \\
\text { location }\end{array}$ & Symptoms & Treatment/outcome \\
\hline & $\mathrm{F}$ & 41 & $\begin{array}{l}\text { Apulia, } \\
\text { Brindisi }\end{array}$ & $\begin{array}{l}\text { Raw marinated sardines } \\
\text { or anchovies consumed } \\
10 \text { days before }\end{array}$ & Anisakis sp. & Laparatomy & Histology & Ileum & Acute appendicitis & Surgery/n.a. \\
\hline & M & 56 & Apulia, Bari & $\begin{array}{l}\text { Raw marinated sardines } \\
\text { or anchovies consumed } \\
\text { few hours before }\end{array}$ & Anisakis sp. & Laparatomy & Histology & Gastric & \multicolumn{2}{|c|}{ Acute abdominal syndrome Surgery/n.a. } \\
\hline & $\mathrm{F}$ & 86 & Apulia, Bari & $\begin{array}{l}\text { Raw marinated sardines } \\
\text { or anchovies habitually } \\
\text { consumed }\end{array}$ & Anisakis sp. & Laparatomy & Histology & Spleen & \multicolumn{2}{|c|}{ Acute abdominal syndrome Surgery/n.a. } \\
\hline & $\mathrm{F}$ & 56 & $\begin{array}{l}\text { Apulia, } \\
\text { Brindisi }\end{array}$ & $\begin{array}{l}\text { Raw marinated sardines } \\
\text { or anchovies consumed } \\
6 \mathrm{~h} \text { before }\end{array}$ & Anisakis sp. & Endoscopy & Microscopy & Gastric & Epigastric pain & $\begin{array}{l}\text { Removal by } \\
\text { endoscopy/n.a. }\end{array}$ \\
\hline $\begin{array}{l}\text { Caramello } \\
\text { et al. [25] }\end{array}$ & $\mathrm{F}$ & 31 & $\begin{array}{l}\text { Liguria, } \\
\quad \text { Savona }(\mathrm{H})\end{array}$ & $\begin{array}{l}\text { Raw or undercooked fish } \\
\text { consumed seven days } \\
\text { before admission }\end{array}$ & Anisakis sp. & Laparatomy & Histology & Ileum & $\begin{array}{l}\text { Severe abdominal colicky } \\
\text { pain, accompanied by } \\
\text { diarrhoea and vomiting }\end{array}$ & $\begin{array}{l}\text { surgery/no } \\
\quad \text { complications }\end{array}$ \\
\hline $\begin{array}{l}\text { Moschella } \\
\text { et al. [83] }\end{array}$ & $\mathrm{F}$ & 37 & $\begin{array}{l}\text { Latium, Rome } \\
\quad(\mathrm{H})\end{array}$ & $\begin{array}{l}\text { Raw marinated anchovies } \\
\text { consumed } 20 \text { days before }\end{array}$ & Anisakis type & 1 Laparatomy & Histology & Colon & $\begin{array}{l}\text { Acute abdominal pain, } \\
\text { nausea and emesis }\end{array}$ & $\begin{array}{l}\text { Surgery }+200 \mathrm{mg} \\
\text { mebendazole b.i.d. } \\
\text { for } 3 \text { days/no } \\
\text { complications }\end{array}$ \\
\hline $\begin{array}{l}\text { De Nicola } \\
\text { et al. [39] }\end{array}$ & M & 40 & $\begin{array}{l}\text { Abruzzo, } \\
\text { Chieti }(\mathrm{H})\end{array}$ & $\begin{array}{l}\text { Raw anchovies consumed } \\
\text { few days before }\end{array}$ & A. simplex & Laparatomy & Histology & Caecum & $\begin{array}{l}\text { Abdominal pain, nausea } \\
\text { and fever }\end{array}$ & $\begin{array}{l}\text { Surgery/no } \\
\text { complications }\end{array}$ \\
\hline $\begin{array}{l}\text { Montalto } \\
\text { et al. [82] }\end{array}$ & M & 41 & $\begin{array}{l}\text { Latium, } \\
\quad \text { Rome }(H)\end{array}$ & $\begin{array}{l}\text { Marinated sardines about } \\
7 \text { days before and } \\
\text { regularly }\end{array}$ & A. simplex & Laparatomy & Histology & Ileum & $\begin{array}{l}\text { Partial intestinal } \\
\text { obstruction evolving } \\
\text { into acute abdomen }\end{array}$ & $\begin{array}{l}\text { Surgery with resection } \\
\text { of the right colon } \\
\text { and the terminal } \\
\text { ileum. } 2 \text { wrong } \\
\text { diagnosis: Chron } \\
\text { and eosinophilic } \\
\text { enteritis. Treatment } \\
\text { with pyrantel } \\
\text { pamoatem, } \\
\text { paromomycin, then } \\
\text { metronidazole and } \\
\text { low doses of } \\
\text { steroids when finally } \\
\text { anisakiasis was } \\
\text { diagnosed (2 years } \\
\text { later)/no } \\
\text { complications }\end{array}$ \\
\hline $\begin{array}{l}\text { Pellegrini } \\
\quad \text { et al. [91] }\end{array}$ & M & 33 & Tuscany, Siena & $\begin{array}{l}\text { Pickled anchovies consumed } \\
\text { a few days before }\end{array}$ & A. simplex & Laparatomy & Histology & Jejunum & $\begin{array}{l}\text { Diffuse abdominal pain } \\
\text { accompanied by } \\
\text { vomiting }\end{array}$ & $\begin{array}{l}\text { Surgery/no } \\
\text { complications }\end{array}$ \\
\hline
\end{tabular}




\begin{tabular}{|c|c|c|c|c|c|c|c|c|c|c|}
\hline Reference & Sex & Age & $\begin{array}{c}\text { Geographical } \\
\text { origin }\end{array}$ & $\begin{array}{l}\text { Source of infection and } \\
\text { time between consumption } \\
\text { and symptoms insurgence }\end{array}$ & $\begin{array}{l}\text { Parasite } \\
\text { species }\end{array}$ & $\begin{array}{l}\text { Method used for } \\
\text { larval detection }\end{array}$ & $\begin{array}{l}\text { Identification } \\
\text { method }\end{array}$ & $\begin{array}{l}\text { Parasite } \\
\text { location }\end{array}$ & Symptoms & Treatment/outcome \\
\hline \multirow[t]{3}{*}{$\begin{array}{l}\text { Fazii et al. } \\
\text { [47] }\end{array}$} & $\mathrm{F}$ & 32 & $\begin{array}{c}\text { Abruzzo, } \\
\text { Chieti }\end{array}$ & $\begin{array}{l}\text { Marinated anchovies } \\
\text { consumed in the } \\
\text { preceeding days }\end{array}$ & Anisakis sp. & Endoscopy & Microscopy & Gastric & Epigastric pain & $\begin{array}{l}\text { Removal by } \\
\text { endoscopy/n.a. }\end{array}$ \\
\hline & M & 66 & $\begin{array}{l}\text { Abruzzo, } \\
\text { Pescara }\end{array}$ & $\begin{array}{l}\text { Marinated anchovies } \\
\text { consumed in the } \\
\text { preceeding days }\end{array}$ & Anisakis sp. & Endoscopy & Microscopy & Gastric & $\begin{array}{l}\text { Gastroscopy for } \\
\text { control }\end{array}$ & $\begin{array}{l}\text { Removal by } \\
\text { endoscopy/n.a. }\end{array}$ \\
\hline & M & 45 & $\begin{array}{l}\text { Abruzzo, } \\
\text { Pescara, } \\
\text { Popoli }\end{array}$ & $\begin{array}{l}\text { Marinated anchovies } \\
\text { consumed in the } \\
\text { preceeding days }\end{array}$ & Anisakis sp. & Endoscopy & Microscopy & Colon & $\begin{array}{l}\text { Colonscopy for } \\
\text { control }\end{array}$ & $\begin{array}{l}\text { Removal by } \\
\text { endoscopy/no } \\
\text { complications } \\
\text { (diet without } \\
\text { seafood and gloves } \\
\text { during work) }\end{array}$ \\
\hline $\begin{array}{l}\text { Avellino et al. } \\
\text { [12] }\end{array}$ & $\mathrm{F}$ & 49 & $\begin{array}{l}\text { Latium, } \\
\quad \text { Rome }(\mathrm{H})\end{array}$ & Not reported & A. pegreffii & Endoscopy & PCR-RFLP & Esophagus & Not described & $\begin{array}{l}\text { Removal by } \\
\text { endoscopy/n.a. }\end{array}$ \\
\hline \multirow[t]{3}{*}{$\begin{array}{l}\text { Ugenti } \\
\text { et al. [117] }\end{array}$} & $\mathrm{F}$ & 51 & $\begin{array}{l}\text { Apulia, Bari } \\
(\mathrm{H})\end{array}$ & $\begin{array}{l}\text { Raw anchovies } \\
\quad \text { consumed } 2 \mathrm{~h} \text { before }\end{array}$ & A. simplex complex & Endoscopy & $\begin{array}{l}\text { Light and } \\
\text { scanning electric } \\
\text { microscopy }\end{array}$ & Gastric & $\begin{array}{l}\text { Very severe } \\
\text { epigastric } \\
\text { pain, vomiting }\end{array}$ & $\begin{array}{l}\text { Removal by } \\
\text { endoscopy/prompt } \\
\text { recovery, no } \\
\text { complications }\end{array}$ \\
\hline & $\mathrm{F}$ & 46 & $\begin{array}{l}\text { Apulia, Bari } \\
\text { (H) }\end{array}$ & $\begin{array}{l}\text { Raw anchovies consumed } \\
12 \mathrm{~h} \text { before }\end{array}$ & A. simplex complex & Endoscopy & $\begin{array}{l}\text { light and scanning } \\
\text { electric } \\
\text { microscopy }\end{array}$ & Gastric & $\begin{array}{l}\text { Severe epigastric } \\
\text { pain without } \\
\text { nausea or vomiting }\end{array}$ & $\begin{array}{l}\text { Removal by } \\
\text { endoscopy/prompt } \\
\text { recovery, no } \\
\text { complications }\end{array}$ \\
\hline & $\mathrm{F}$ & 61 & $\begin{array}{l}\text { Apulia, Bari } \\
(\mathrm{H})\end{array}$ & $\begin{array}{l}\text { Raw anchovies consumed } \\
12 \mathrm{~h} \text { before }\end{array}$ & A. simplex complex & Endoscopy & $\begin{array}{l}\text { light and scanning } \\
\text { electric } \\
\text { microscopy }\end{array}$ & Gastric & $\begin{array}{l}\text { Violent epigastric } \\
\text { pain }\end{array}$ & $\begin{array}{l}\text { Removal by } \\
\text { endoscopy/prompt } \\
\text { recovery, no } \\
\text { complications }\end{array}$ \\
\hline \multirow[t]{2}{*}{$\begin{array}{l}\text { Fumarola } \\
\text { et al. [49] }\end{array}$} & $\mathrm{F}$ & 49 & Apulia, Bari & $\begin{array}{l}\text { Homemade raw pickled } \\
\text { (vinegar) anchovies } \\
\text { consumed } 6 \mathrm{~h} \text { before }\end{array}$ & $\begin{array}{l}\text { L3 larva of the } \\
\text { genus Anisakis } \\
\text { on the basis } \\
\text { of morphological } \\
\text { criteria. } \text { A. pegreffii } \\
\text { by PCR-RFLP }\end{array}$ & Endoscopy & $\begin{array}{r}\text { Microscopy }+ \\
\text { PCR-RFLP }\end{array}$ & Gastric & $\begin{array}{l}\text { Bloody vomiting } \\
\text { and severe gastric } \\
\text { pain }\end{array}$ & $\begin{array}{l}\text { Removal by } \\
\text { endoscopy/prompt } \\
\text { recovery, no } \\
\text { complications }\end{array}$ \\
\hline & $\mathrm{F}$ & 59 & Apulia, Bari & $\begin{array}{l}\text { Regular eater of undercookec } \\
\text { fish }\end{array}$ & $\begin{array}{l}\text { dL3 larva of the } \\
\text { genus Anisakis } \\
\text { on the basis } \\
\text { of morphological } \\
\text { criteria. } \text { A. pegreffii } \\
\text { by PCR-RFLP }\end{array}$ & Endoscopy & $\begin{array}{r}\text { Microscopy }+ \\
\text { PCR-RFLP }\end{array}$ & Gastric & $\begin{array}{l}\text { Gastric pain and } \\
\text { meteorism }\end{array}$ & $\begin{array}{l}\text { Removal by } \\
\text { endoscopy/n.a. }\end{array}$ \\
\hline $\begin{array}{l}\text { Marzocca } \\
\text { et al. [67] }\end{array}$ & M & 33 & $\begin{array}{l}\text { Tuscany, } \\
\text { Siena }\end{array}$ & $\begin{array}{l}\text { Marinated anchovies } \\
\text { consumed in the } \\
\text { preceeding days }\end{array}$ & A. simplex & Laparatomy & Histology & Jejunum & $\begin{array}{l}\text { Severe upper } \\
\text { abdominal pain, } \\
\text { nausea and } \\
\text { vomiting, without } \\
\text { fever }\end{array}$ & $\begin{array}{l}\text { Surgery/no } \\
\text { complications }\end{array}$ \\
\hline
\end{tabular}


(continued)

\begin{tabular}{|c|c|c|c|c|c|c|c|c|c|c|}
\hline Reference & Sex & Age & $\begin{array}{l}\text { Geographical } \\
\text { origin }\end{array}$ & $\begin{array}{l}\text { Source of infection and } \\
\text { time between consumption and } \\
\text { symptoms insurgence }\end{array}$ & $\begin{array}{l}\text { Parasite } \\
\text { species }\end{array}$ & $\begin{array}{l}\text { Method used fo } \\
\text { larval detection }\end{array}$ & $\begin{array}{l}\text { r Identification } \\
\text { method }\end{array}$ & $\begin{array}{l}\text { Parasite } \\
\text { location }\end{array}$ & Symptoms & Treatment/outcome \\
\hline Aloia et al. [3] & M & 32 & $\begin{array}{l}\text { Campania, Salerno } \\
(\mathrm{H})\end{array}$ & $\begin{array}{l}\text { Raw marinated anchovies } \\
\text { consumed three days before } \\
\text { the colonoscopy }\end{array}$ & A. simplex & Endoscopy & Microscopy & Colon & $\begin{array}{l}\text { Rectal bleeding with no } \\
\text { other symptomatology }\end{array}$ & $\begin{array}{l}\text { Removal by endoscopy } \\
\text { + albendazole ( } 400 \\
\text { mg b.i.d. for } 4 \text { days) } \\
\text { no complications } \\
\text { (diet without } \\
\text { seafood) }\end{array}$ \\
\hline $\begin{array}{l}\text { Mattiucci et al. } \\
\text { [74] }\end{array}$ & M & & $\begin{array}{l}\text { Latium, } \\
\quad \text { Viterbo }\end{array}$ & $\begin{array}{l}\text { Raw anchovies consumed } 2 \\
\text { months before }\end{array}$ & A. pegreffii & Laparatomy & $\begin{array}{l}\text { DNA } \\
\text { extraction } \\
\text { technique } \\
\text { from } \\
\text { paraffin- } \\
\text { embedded } \\
\text { tissue, } \\
\text { followed } \\
\text { by PCR } \\
\text { (cox } 2)\end{array}$ & Caecum & $\begin{array}{l}\text { Acute abdominal } \\
\text { pain in the lower } \\
\text { right quadrant, nausea } \\
\text { and emesis }\end{array}$ & Surgery/n.a. \\
\hline \multirow[t]{11}{*}{ De Rosa [40] } & $\mathrm{F}$ & 19 & $\begin{array}{l}\text { Abruzzo, Chieti, } \\
\text { Guardiagrele }\end{array}$ & $\begin{array}{l}\text { Habitual consumption of } \\
\text { marinated anchovies }\end{array}$ & Anisakis sp. & Laparatomy & Histology & Caecum & Acute abdomen & Surgery/n.a. \\
\hline & M & 38 & Abruzzo, Pescara & $\begin{array}{l}\text { Habitual consumption of } \\
\text { marinated anchovies }\end{array}$ & Anisakis sp. & Laparatomy & Histology & Ileum & Acute abdomen & Surgery/n.a. \\
\hline & M & 32 & Abruzzo, Pescara & $\begin{array}{l}\text { Marinated anchovies } \\
\text { consumed } 7 \text { days before }\end{array}$ & Anisakis sp. & Laparatomy & Histology & Ileum & Acute abdomen & Surgery/n.a. \\
\hline & M & 39 & $\begin{array}{l}\text { Abruzzo, Chieti, } \\
\text { Ortona a Mare }\end{array}$ & $\begin{array}{l}\text { Habitual consumption of } \\
\text { marinated anchovies }\end{array}$ & Anisakis sp. & Laparatomy & Histology & Ileum & Acute abdomen & Surgery/n.a. \\
\hline & $\mathrm{M}$ & 51 & Abruzzo, Pescara & $\begin{array}{l}\text { Habitual consumption of } \\
\text { marinated anchovies }\end{array}$ & Anisakis sp. & Laparatomy & Histology & Colon & Acute abdomen & Surgery/n.a. \\
\hline & $\mathrm{F}$ & 35 & $\begin{array}{l}\text { Abruzzo, Chieti, } \\
\text { Ortona a Mare }\end{array}$ & $\begin{array}{l}\text { Marinated anchovies } \\
\text { consumed a few } \\
\text { days before }\end{array}$ & Anisakis sp. & Laparatomy & Histology & Ileum & Acute abdomen & Surgery/n.a. \\
\hline & M & 40 & Abruzzo, Chieti & $\begin{array}{l}\text { Marinated anchovies } \\
\text { consumed a few days } \\
\text { before }\end{array}$ & Anisakis sp. & Laparatomy & Histology & Caecum & Acute abdomen & Surgery/n.a. \\
\hline & M & 67 & Abruzzo, Chieti & $\begin{array}{l}\text { Habitual consumption of } \\
\text { marinated anchovies }\end{array}$ & Anisakis sp. & Laparatomy & Histology & Colon & Light abdominal pain & Surgery/n.a. \\
\hline & $\mathrm{F}$ & 27 & $\begin{array}{l}\text { Abruzzo, Chieti, } \\
\text { Vasto }\end{array}$ & $\begin{array}{l}\text { Marinated anchovies } \\
\text { consumed a few days } \\
\text { before }\end{array}$ & Anisakis sp. & Laparatomy & Histology & Ileum & Abdominal pain & Surgery/n.a. \\
\hline & M & 59 & $\begin{array}{l}\text { Abruzzo, Chieti, } \\
\text { Lanciano }\end{array}$ & $\begin{array}{l}\text { Marinated anchovies } \\
\text { consumed } 24 \mathrm{~h} \text { before }\end{array}$ & Anisakis sp. & Endoscopy & Microscopy & Colon & Acute abdomen & $\begin{array}{l}\text { Removal by } \\
\text { endoscopy/n.a. }\end{array}$ \\
\hline & $\mathrm{F}$ & 38 & $\begin{array}{l}\text { Molise, } \\
\text { Montecilfone } \\
\text { (CB) }\end{array}$ & $\begin{array}{l}\text { Marinated anchovies (only } \\
\text { one anchovy) consumed } \\
12 \mathrm{~h} \text { before }\end{array}$ & Anisakis sp. & Laparatomy & Histology & Ileum & Acute abdomen & Surgery/n.a. \\
\hline
\end{tabular}




\begin{tabular}{|c|c|c|c|c|c|c|c|c|c|c|}
\hline Reference & Sex & Age & $\begin{array}{l}\text { Geographical } \\
\text { origin }\end{array}$ & $\begin{array}{l}\text { Source of infection and } \\
\text { time between consumption and } \\
\text { symptoms insurgence }\end{array}$ & $\begin{array}{l}\text { Parasite } \\
\text { species }\end{array}$ & $\begin{array}{l}\text { Method used for } \\
\text { larval detection }\end{array}$ & $\begin{array}{l}\text { Identification } \\
\text { method }\end{array}$ & $\begin{array}{l}\text { Parasite } \\
\text { location }\end{array}$ & Symptoms & Treatment/outcome \\
\hline & $\mathrm{F}$ & 45 & $\begin{array}{l}\text { Abruzzo, } \\
\text { Teramo }\end{array}$ & $\begin{array}{l}\text { Marinated anchovies a } \\
\text { few days before }\end{array}$ & Anisakis sp. & Endoscopy & Microscopy & Colon & Abdominal pain & $\begin{array}{l}\text { Removal by } \\
\text { endoscopy/n.a. }\end{array}$ \\
\hline & $\mathrm{F}$ & 44 & $\begin{array}{l}\text { Abruzzo, } \\
\text { Teramo, } \\
\text { Campli }\end{array}$ & $\begin{array}{l}\text { Marinated anchovies } \\
\text { consumed } 4 \mathrm{~h} \text { before }\end{array}$ & Anisakis sp. & Endoscopy & Microscopy & Gastric & Epigastric pain & $\begin{array}{l}\text { Removal by } \\
\text { endoscopy/n.a. }\end{array}$ \\
\hline & M & 30 & $\begin{array}{l}\text { Abruzzo, Chieti, } \\
\text { Francavilla al } \\
\text { Mare }\end{array}$ & $\begin{array}{l}\text { i, Marinated anchovies } \\
1 \text { consumed } 12 \mathrm{~h} \text { before }\end{array}$ & Anisakis sp. & Endoscopy & Microscopy & Gastric & Epigastric pain & $\begin{array}{l}\text { Removal by } \\
\text { endoscopy/n.a. }\end{array}$ \\
\hline & $\mathrm{F}$ & 28 & Abruzzo, Chieti & $\begin{array}{l}\text { i Sushi consumed a few days } \\
\text { before at a restaurant }\end{array}$ & Anisakis sp. & Laparatomy & Histology & Mesentery & yAcute abdomen & Surgery/n.a. \\
\hline \multicolumn{2}{|c|}{ Pontone et al. [96]F } & 55 & $\begin{array}{l}\text { Latium, Rome } \\
\quad(\mathrm{H})\end{array}$ & $\begin{array}{l}\text { Marinated anchovies } \\
\text { consumed } 12 \mathrm{~h} \text { before }\end{array}$ & Anisakis sp. & Endoscopy & Microscopy & Gastric & $\begin{array}{l}\text { Acute chest discomfort, } \\
\text { no abdominal pain }\end{array}$ & $\begin{array}{l}\text { Removal by } \\
\text { endoscopy/prompt } \\
\text { recovery, no } \\
\text { complications }\end{array}$ \\
\hline \multirow[t]{8}{*}{$\begin{array}{l}\text { Mattiucci et al. } \\
\text { [71] }\end{array}$} & n.a. & n.a. & $\begin{array}{l}\text { Campania, } \\
\text { Benevento }\end{array}$ & $\begin{array}{l}\text { Raw fresh marinated } \\
\text { anchovies consumed } \\
2 \mathrm{~h} \text { before }\end{array}$ & A. pegreffii & Endoscopy & $\begin{array}{l}\text { PCR (cox II, } \\
\text { ITS region) }\end{array}$ & Gastric & $\begin{array}{l}\text { Epigastric pain, edema } \\
\text { of oral mucosa }\end{array}$ & $\begin{array}{l}\text { Removal by } \\
\text { endoscopy/n.a. }\end{array}$ \\
\hline & n.a. & n.a. & $\begin{array}{l}\text { Abruzzo, } \\
\text { Pescara }\end{array}$ & $\begin{array}{l}\text { Raw fresh marinated } \\
\text { anchovies consumed } \\
24 \mathrm{~h} \text { before }\end{array}$ & A. pegreffii & Endoscopy & $\begin{array}{l}\text { PCR (cox II, } \\
\text { ITS region) }\end{array}$ & Gastric & $\begin{array}{l}\text { Epigastric pain, urticaria, } \\
\text { generalized edema }\end{array}$ & $\begin{array}{l}\text { Removal by } \\
\text { endoscopy/n.a. }\end{array}$ \\
\hline & n.a. & n.a. & $\begin{array}{l}\text { Abruzzo, } \\
\text { Pescara }\end{array}$ & $\begin{array}{l}\text { Raw fresh marinated } \\
\text { anchovies consumed } \\
24 \mathrm{~h} \text { before }\end{array}$ & A. pegreffii & Endoscopy & $\begin{array}{l}\text { PCR (cox II, } \\
\text { ITS region) }\end{array}$ & Gastric & Epigastric pain & $\begin{array}{l}\text { Removal by } \\
\text { endoscopy/n.a. }\end{array}$ \\
\hline & n.a. & n.a. & $\begin{array}{l}\text { Abruzzo, } \\
\text { Pescara }\end{array}$ & $\begin{array}{l}\text { Raw fresh marinated } \\
\text { anchovies consumed } \\
1 \text { day before }\end{array}$ & A. pegreffii & Endoscopy & $\begin{array}{l}\text { PCR (cox II, } \\
\text { ITS region) }\end{array}$ & Gastric & $\begin{array}{l}\text { Epigastric pain, digestive } \\
\text { symptoms }\end{array}$ & $\begin{array}{l}\text { Removal by } \\
\text { endoscopy/n.a. }\end{array}$ \\
\hline & n.a. & n.a. & $\begin{array}{l}\text { Abruzzo, } \\
\text { Pescara }\end{array}$ & $\begin{array}{l}\text { Raw fresh marinated } \\
\text { anchovies consumed } \\
1 \text { day before }\end{array}$ & A. pegreffii & Endoscopy & $\begin{array}{l}\text { PCR (cox II, } \\
\text { ITS region) }\end{array}$ & Gastric & Epigastric pain & $\begin{array}{l}\text { Removal by } \\
\text { endoscopy/n.a. }\end{array}$ \\
\hline & n.a. & n.a. & Latium, Rome & $\begin{array}{l}\text { Raw fresh marinated } \\
\text { anchovies consumed } \\
1 \text { day before }\end{array}$ & A. pegreffii & Endoscopy & $\begin{array}{l}\text { PCR (cox II, } \\
\text { ITS region) }\end{array}$ & Gastric & Epigastric pain, urticaria & $\begin{array}{l}\text { Removal by } \\
\text { endoscopy/n.a. }\end{array}$ \\
\hline & n.a. & n.a. & Tuscany, Pisa & $\begin{array}{l}\text { Raw fresh marinated } \\
\text { anchovies consumed } \\
2 \text { days before }\end{array}$ & A. pegreffii & Endoscopy & $\begin{array}{l}\text { PCR (cox II, } \\
\text { ITS region) }\end{array}$ & Gastric & Epigastric pain, vomiting & $\begin{array}{l}\text { Removal by } \\
\text { endoscopy/n.a. }\end{array}$ \\
\hline & n.a. & n.a. & $\begin{array}{l}\text { Campania, } \\
\text { Naples }\end{array}$ & $\begin{array}{l}\text { Raw fresh marinated } \\
\text { anchovies consumed } \\
2-3 \mathrm{~h} \text { before }\end{array}$ & A. pegreffii & Endoscopy & $\begin{array}{l}\text { PCR (cox II, } \\
\text { ITS region) }\end{array}$ & Gastric & Epigastric pain & $\begin{array}{l}\text { Removal by } \\
\text { endoscopy/n.a. }\end{array}$ \\
\hline $\begin{array}{l}\text { Mumoli and } \\
\text { Merlo [84] }\end{array}$ & M & 56 & $\begin{array}{l}\text { Tuscany, } \\
\quad \text { Livorno (H) }\end{array}$ & $\begin{array}{l}\text { Sushi and sashimi consumed } \\
\text { at a restaurant a month } \\
\text { before }\end{array}$ & A. simplex & Endoscopy & Histology & Colon & $\begin{array}{l}\text { Nausea and colicky pain } \\
\text { in the lower left } \\
\text { abdominal quadrant }\end{array}$ & $\begin{array}{l}\text { Removal by } \\
\text { endoscopy/n.a. }\end{array}$ \\
\hline
\end{tabular}




\begin{tabular}{|c|c|c|c|c|c|c|c|c|c|c|}
\hline Reference & Sex & Age & $\begin{array}{l}\text { Geographical } \\
\text { origin }\end{array}$ & $\begin{array}{l}\text { Source of infection and } \\
\text { time between consumption and } \\
\text { symptoms insurgence }\end{array}$ & $\begin{array}{l}\text { Parasite } \\
\text { species }\end{array}$ & $\begin{array}{l}\text { Method used for } \\
\text { larval detection }\end{array}$ & $\begin{array}{c}\text { Identification } \\
\text { method }\end{array}$ & $\begin{array}{l}\text { Parasite } \\
\text { location }\end{array}$ & Symptoms & Treatment/outcome \\
\hline $\begin{array}{l}\text { Andrisani et al. } \\
{[5]}\end{array}$ & $\mathrm{F}$ & 56 & $\begin{array}{l}\text { Latium, Rome } \\
(\mathrm{H})\end{array}$ & $\begin{array}{l}\text { Raw fish (time of } \\
\text { consumption unknown) }\end{array}$ & Anisakis sp. & Endoscopy & Histology & Colon & $\begin{array}{l}\text { Abdominal pain, nausea, } \\
\text { vomiting and diarrhoea }\end{array}$ & Surgery/n.a. \\
\hline Baron et al. [15] & M & 20 & $\begin{array}{l}\text { Not clear } \\
\text { (Campania or } \\
\text { Sicily) }\end{array}$ & $\begin{array}{l}\text { Raw anchovies consumed } 7 \\
r \quad \text { days before the symptoms }\end{array}$ & Anisakis sp. & Laparatomy & Histology & Ileum & $\begin{array}{l}\text { Abdominal pain and } \\
\text { vomiting }\end{array}$ & $\begin{array}{l}\text { Surgery/no } \\
\text { complications }\end{array}$ \\
\hline $\begin{array}{l}\text { Mariano et al. } \\
{[65]}\end{array}$ & $\mathrm{F}$ & 53 & Latium, Rome & $\begin{array}{l}\text { Marinated anchovies consumed } \\
\text { the night before onset of } \\
\text { gastric symptoms }\end{array}$ & Anisakis sp. & Endoscopy & Histology & Gastric & $\begin{array}{l}\text { Intense stomach ache } \\
\text { associated with aspecific } \\
\text { chest pain }\end{array}$ & $\begin{array}{l}\text { Removal by } \\
\text { endoscopy/prompt } \\
\text { recovery, no } \\
\text { complications }\end{array}$ \\
\hline $\begin{array}{l}\text { Carbotta et al. } \\
\text { [26] }\end{array}$ & M & 61 & Apulia, Bari & $\begin{array}{l}\text { Raw fish consumed } 3 \text { days } \\
\text { before admission }\end{array}$ & Anisakis sp. & Laparatomy & Histology & Ileum & $\begin{array}{l}\text { Abdominal pain, vomit and } \\
\text { constipation }\end{array}$ & $\begin{array}{l}\text { dSurgery/no } \\
\text { complications }\end{array}$ \\
\hline \multirow[t]{5}{*}{$\begin{array}{l}\text { Mattiucci } \\
\quad \text { et al [70] }\end{array}$} & n.a. & n.a. & n.a. & Marinated anchovies & A. pegreffii & Endoscopy & PCR (COII) & Gastric & $\begin{array}{l}\text { Gastro-allergic } \\
\text { anisakiasis }\end{array}$ & endoscopy/n.a. \\
\hline & n.a. & n.a. & n.a. & Marinated anchovies & A. pegreffii & Endoscopy & PCR (COII) & Gastric & $\begin{array}{l}\text { Gastro-allergic } \\
\text { anisakiasis }\end{array}$ & endoscopy/n.a. \\
\hline & n.a. & n.a. & n.a. & Marinated anchovies & A. pegreffii & Endoscopy & PCR (COII) & Gastric & $\begin{array}{l}\text { Gastro-allergic } \\
\text { anisakiasis }\end{array}$ & endoscopy/n.a. \\
\hline & n.a. & n.a. & n.a. & Marinated anchovies & A. pegreffii & Endoscopy & PCR (COII) & Gastric & $\begin{array}{l}\text { Gastro-allergic } \\
\text { anisakiasis }\end{array}$ & endoscopy/n.a. \\
\hline & n.a. & n.a. & n.a. & Marinated anchovies & A. pegreffii & Endoscopy & PCR (COII) & Gastric & $\begin{array}{c}\text { Gastro-allergic } \\
\text { anisakiasis }\end{array}$ & endoscopy/n.a. \\
\hline \multirow[t]{3}{*}{$\begin{array}{l}\text { Mattiucci } \\
\text { et al. [75] }\end{array}$} & $\mathrm{F}$ & n.a. & $\begin{array}{l}\text { Abruzzo, } \\
\text { Pescara }\end{array}$ & $\begin{array}{l}\text { Home-made raw marinated } \\
\text { anchovies }\end{array}$ & A. pegreffii & Endoscopy & $\begin{array}{l}\text { PCR }(\mathrm{COII} \text { and } \\
\text { EF1 } \alpha-1 \\
\text { nDNA region })\end{array}$ & Gastric & $\begin{array}{l}\text { Epigastric pain } \\
\text { and nausea }\end{array}$ & $\begin{array}{l}\text { Removal by } \\
\text { endoscopy/prompt } \\
\text { recovery, no } \\
\text { complications }\end{array}$ \\
\hline & M & 58 & $\begin{array}{l}\text { Latium, } \\
\text { Rome }\end{array}$ & $\begin{array}{l}\text { Home-made raw marinated } \\
\text { anchovies consumed a } \\
\text { week before, and } 2 \text { days after } \\
\text { consumption the symptoms } \\
\text { appeared }\end{array}$ & A. pegreffii & Endoscopy & $\begin{array}{l}\text { PCR }(\mathrm{COII} \text { and } \\
\text { EF1 } \alpha-1 \\
\text { nDNA region })\end{array}$ & Colon & $\begin{array}{l}\text { Sense of oppression } \\
\text { in the right side } \\
\text { of the abdomen }\end{array}$ & $\begin{array}{l}\text { Removal by } \\
\text { endoscopy/prompt } \\
\text { recovery, no } \\
\text { complications }\end{array}$ \\
\hline & M & 35 & $\begin{array}{l}\text { Tuscany, } \\
\text { Livorno }\end{array}$ & $\begin{array}{l}\text { Home-made raw marinated } \\
\text { anchovies consumed } \\
10 \text { days prior to hospital } \\
\text { admission }\end{array}$ & A. pegreffii & Laparatomy & $\begin{array}{l}\text { RT-PCR } \\
\text { hydrolysis } \\
\text { probe system - } \\
\text { based on } \\
\text { mtDNA cox2 }\end{array}$ & $\begin{array}{l}\text { Colon } \\
-\end{array}$ & $\begin{array}{l}\text { Abdominal pain, } \\
\text { nausea and fever }\end{array}$ & Surgery/n.a. \\
\hline $\begin{array}{l}\text { Palma } \\
\text { et al. [89] }\end{array}$ & $\mathrm{F}$ & 52 & $\begin{array}{l}\text { Latium, } \\
\quad \text { Rome }(\mathrm{H})\end{array}$ & $\begin{array}{l}\text { Raw anchovies consumed } \\
\text { at a sushi restaurant } \\
5 \text { days before }\end{array}$ & Anisakis sp. & Endoscopy & Histology & Gastric & $\begin{array}{l}\text { Epigastric pain and } \\
\text { gastroesophageal } \\
\text { reflux disease }\end{array}$ & $\begin{array}{l}\text { Removal by } \\
\text { endoscopy/n.a. }\end{array}$ \\
\hline
\end{tabular}

H: geographical location attributed on the basis of the hospital; n.a. = not available. 